\title{
Oak Ridge National Laboratory Small Business Voucher CRADA Report: Natural Gas Powered HVAC System for Commercial and Residential Buildings
}

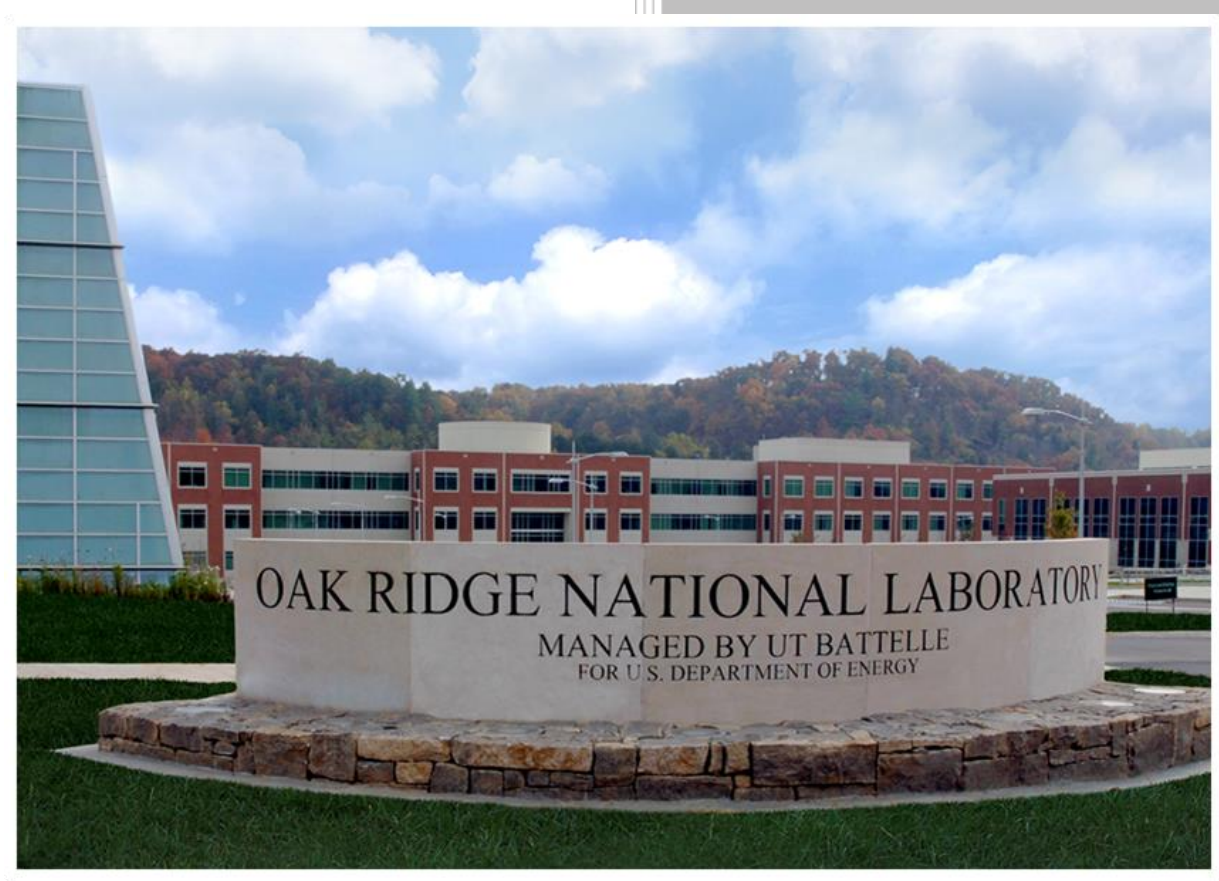

Approved for public release. Distribution is unlimited.
Daniel Betts (PI) Moonis Ally (PI) Shyam Mudiraj Matthew Tilghman Matthew Graham

Date April 30, 2017 


\title{
DOCUMENT AVAILABILITY
}

Reports produced after January 1, 1996, are generally available free via US Department of Energy (DOE) SciTech Connect.

Website http://www.osti.gov/scitech/

Reports produced before January 1, 1996, may be purchased by members of the public from the following source:

\author{
National Technical Information Service \\ 5285 Port Royal Road \\ Springfield, VA 22161 \\ Telephone 703-605-6000 (1-800-553-6847) \\ TDD 703-487-4639 \\ Fax 703-605-6900 \\ E-mail info@ntis.gov \\ Website http://classic.ntis.gov/
}

Reports are available to DOE employees, DOE contractors, Energy Technology Data Exchange representatives, and International Nuclear Information System representatives from the following source:

Office of Scientific and Technical Information

PO Box 62

Oak Ridge, TN 37831

Telephone 865-576-8401

Fax 865-576-5728

E-mail reports@osti.gov

Website http://www.osti.gov/contact.html

This report was prepared as an account of work sponsored by an agency of the United States Government. Neither the United States Government nor any agency thereof, nor any of their employees, makes any warranty, express or implied, or assumes any legal liability or responsibility for the accuracy, completeness, or usefulness of any information, apparatus, product, or process disclosed, or represents that its use would not infringe privately owned rights. Reference herein to any specific commercial product, process, or service by trade name, trademark, manufacturer, or otherwise, does not necessarily constitute or imply its endorsement, recommendation, or favoring by the United States Government or any agency thereof. The views and opinions of authors expressed herein do not necessarily state or reflect those of the United States Government or any agency thereof. 


\author{
Energy and Transportation Science Division \\ $\&$ \\ Office of Technology Transfer
}

\title{
SMALL BUSINESS VOUCHER (SBV) CRADA REPORT: NATURAL GAS POWERED HVAC SYSTEM FOR COMMERCIAL AND RESIDENTIAL BUILDINGS
}

\author{
Daniel Betts, Be Power Tech \\ Moonis Ally (ORNL) \\ Shyam Mudiraj, Be Power Tech \\ Matthew Tilghman, Be Power Tech \\ Matthew Graham, Be Power Tech
}

Date Published: April 30, 2016

\author{
Prepared by \\ OAK RIDGE NATIONAL LABORATORY \\ Oak Ridge, TN 37831-6283 \\ managed by \\ UT-BATTELLE, LLC \\ for the \\ US DEPARTMENT OF ENERGY \\ under contract DE-AC05-00OR22725
}

Approved for

U.S. Department of Energy, Building Technology Office 



\section{CONTENTS}

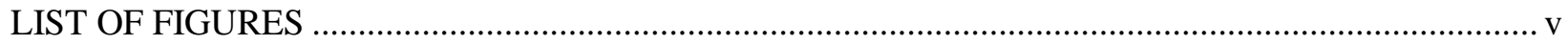

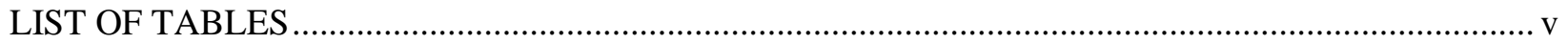

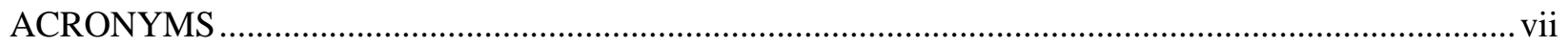

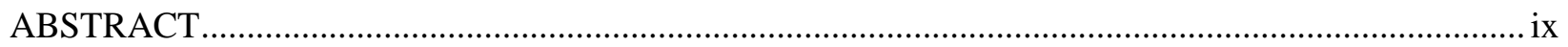

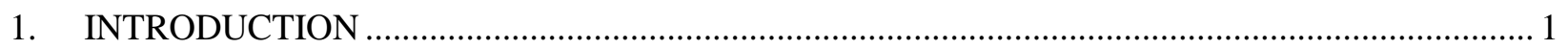

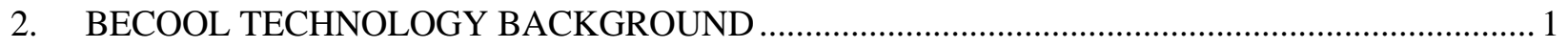

2.1 DESCRIPTION OF OPERATING PRINCIPLE ................................................... 2

2.1.1 A More Effective Cooling Process .................................................................... 3

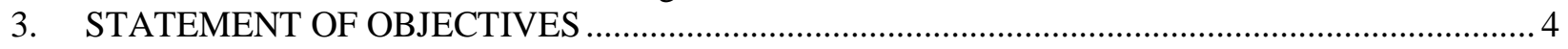

4. BENEFIT TO THE FUNDING DEPARTMENT OF ENERGY'S MISSION …............................. 4

4.1 REDUCE BUILDING ENERGY CONSUMPTION PER SQUARE FOOT .........................5

4.1.1 Primary Energy Savings Technical Potential (PESTP) Calculation ............................. 5

4.1.2 Calculation of Primary Energy Consumption of BeCool System................................ 5

4.1.3 Primary Energy Consumption of Commercial RTU AC ............................................ 6

4.1.4 Primary Energy Consumption of Natural Gas Heaters ............................................... 6

4.1.5 Primary Energy Consumption of Electric Heaters ..................................................... 7

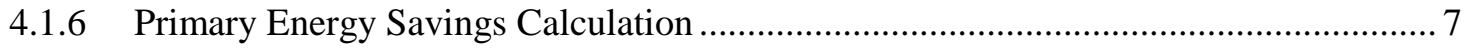

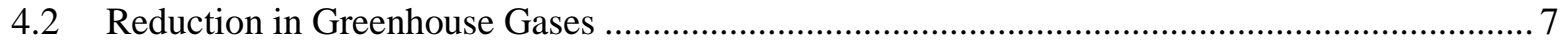

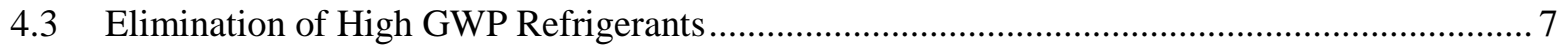

4.4 Greenhouse Gas Emission Reductions through Building Efficiency.................................... 8

4.5 Enabling Increased Renewable Energy Deployment .........................................................

5. TECHNICAL DISCUSSION OF WORK PERFORMED BY ALL PARTIES ............................... 11

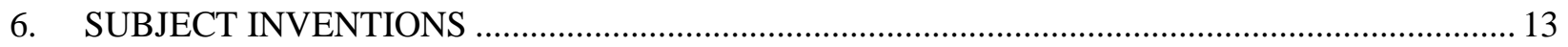

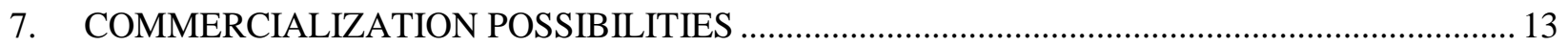

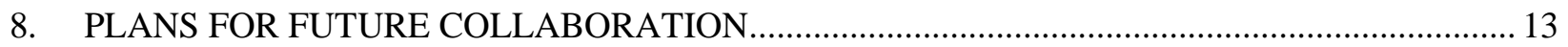

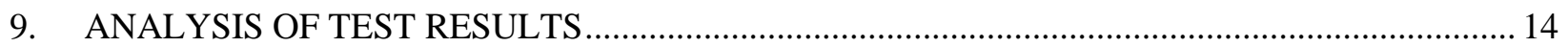

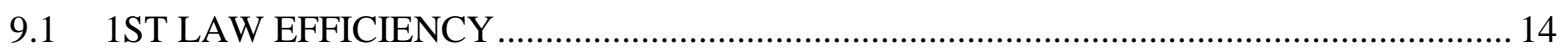

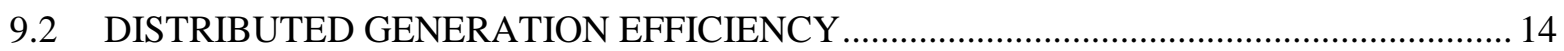

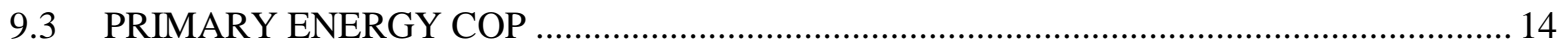

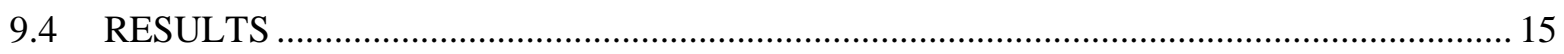

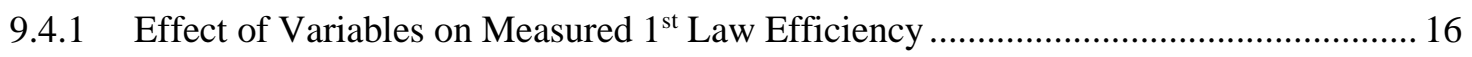

9.4.2 High Humidity/High Temperature Outdoor Air Results ......................................... 17

9.4.3 Performance Evaluation Accounting for HVAC Daily Duty Cycle: .......................... 18

9.4.4 Low Humidity/High Temperature Outdoor Air Results ............................................ 20

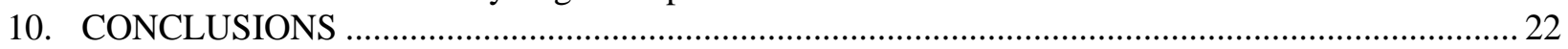

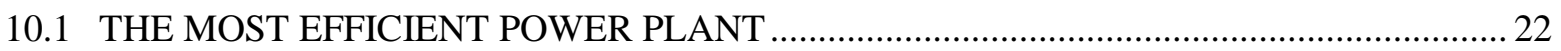

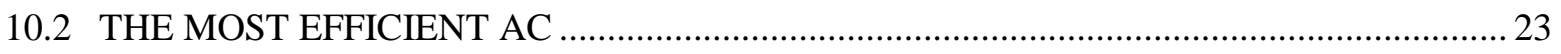

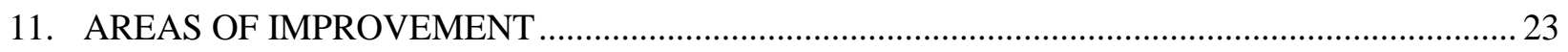

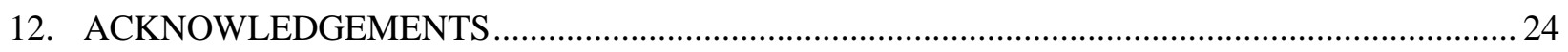

APPENDIX A. SUMMARY OF ALL TESTS PERFORMED .................................................. A-1 



\section{LIST OF FIGURES}

Figure 1. BeCool system general operating diagram. [Air temperatures and humidity points shown are for exemplary reference and do not correspond to test results] ................................... 3

Figure 2. Difference in air conditioning process between a vapor compression cycle (VCC) and an enhanced liquid desiccant evaporative cooling air conditioner (ELD/AC) cycle.

Figure 3. General conversion of primary energy to final energy products for the BeCool technology

Figure 4. Results of modeling conducted by Be Power Tech shows $\mathrm{CO}_{2}$ emissions reductions of a BeCool system ranges between $26 \%-61 \%$ in comparison to conventional power generation and RTU HVAC technology.

Figure 5. The duck curve.

Figure 6. The BeCool prototype (top) being readied for shipment, and its installation (bottom) in the environmental chamber at ORNL.

Figure 7. Major components of the BeCool prototype unit.

Figure 8. Summary of outdoor air tests conducted and the 1st law efficiency achieved by the BeCool system.

Figure 9. 1st law efficiency of prototype BeCool system.

Figure 10. Sorted absolute value of correlation between input and measured test variables and 1st law efficiency measured during steady state testing.

Figure 11. Psychrometric chart showing the states achieved by the prototype BeCool unit.

Figure 12. Distributed Generation Efficiency $\left(\eta_{D G}\right)$ as a function of duty cycle $(\epsilon)$ for a fuel cell system and for an internal combustion system assuming outdoor air and SA conditions are constant.

Figure 13. Psychrometric chart showing the states achieved by the prototype BeCool unit.

Figure 14. Distributed Generation Efficiency $\left(\eta_{D G}\right)$ as a function of duty cycle $(\epsilon)$ for a fuel cell system and for an internal combustion system assuming outdoor air and SA conditions are constant.

Figure 15. Primary energy savings potential of BeCool compared to other advanced air conditioning technologies. The baseline of zero is conventional vapor compression technology.....

\section{LIST OF TABLES}

Table 1. Results of primary energy savings technical potential of the BeCool technology

Table 2. Primary energy savings of BeCool technology

Table 3. Estimate of GWP of conventional AC using R140A refrigerants

Table 4. Efficiency calculation for BeCool system based on tested data

Table 5. Efficiency calculation for BeCool system based on tested data 



\section{ACRONYMS}

\begin{tabular}{ll} 
AC & air conditioner \\
C & cooling \\
COP & coefficient of performance \\
CRADA & cooperative research and development agreement \\
DA & dehumidified air \\
DOE & Department of Energy \\
E & electrical energy \\
ELD-AC & enhanced liquid desiccant evaporative cooling air conditioner \\
F & heat energy in fuel, lower heating value based \\
GWP & global warming potential \\
H & heat energy \\
HMX & heat and mass exchanger \\
HMX1 & heat and mass exchanger for desiccant regeneration \\
HMX2 & heat and mass exchanger for process air dehumidification \\
HMX3 & heat and mass exchanger for indirect cooling \\
HVAC & heating, ventilation, and air conditioning \\
IEC & indirect evaporative cooling \\
MA & mixed air \\
OA & outside air \\
ORNL & Oak Ridge National Laboratory \\
PA & process air \\
PE & primary energy \\
PESTP & primary energy savings technical potential \\
RA & return air \\
RH & relative humidity \\
RTU & roof top unit \\
SA & supply air \\
SBV & small business voucher \\
VCC & vapor compression cycle \\
& \\
\hline
\end{tabular}





\begin{abstract}
Be Power Tech is commercializing BeCool, the first integrated electricity-producing heating, ventilation, and air conditioning (HVAC) system using a non-vapor compression cycle (VCC), packaged rooftop HVAC unit that also produces base-load electricity, heating, ventilation, and air conditioning. BeCool is a distributed energy resource with energy storage that eliminates the tremendous peak electricity demand associated with commonly used electricity-powered vapor compression air conditioning systems.
\end{abstract}

BeCool could enable the proliferation of renewable resources into the electric grid, reduce greenhouse gas emissions, eliminate the use of refrigerants used for air conditioning, and provide significant cost savings for utilities and ratepayers. BeCool eliminates grid-powered electricity for building air conditioning, coincident peak demand and associated spinning reserves, aiding in the flattening of the "duck curve."

BeCool transforms the common packaged rooftop unit into a cost effective distributed energy resource, opening a new range of small applications and broad markets for micro-combined cycle cooling, heating, and power with integral thermal energy storage.

Be Power Tech plans to initially commercialize a 5 ton $/ 5 \mathrm{~kW}$ BeCool systems. Each unit eliminates $\sim 10 \mathrm{~kW}$ of peak electrical demand, generates up to $43 \mathrm{MWh} / \mathrm{yr}$ of electricity, and saves roughly $10 \mathrm{MWh} / \mathrm{yr}$ that would have been used to run a conventional air conditioner.

BeCool is scalable from 2 to 20 tons and is applicable to $98 \%$ of US commercial buildings. The current state of the electricity-producing HVAC is technology readiness level (TRL) 5 following the testing of the prototype at Oak Ridge National Laboratory executed under the CRADA, which this report summarizes.

The results of the tests indicate that the BeCool system, as tested would be competitive with natural gas distributed powerplants with average electrical power efficiency of ranging from $45 \%$ to $60 \%$. Test results indicate that the technology has a Primary Energy Savings Potential of 4.4 Quads; higher than any other air conditioning and heating technology. 



\section{INTRODUCTION}

Be Power Tech has developed a novel combined power and heating, ventilation, and air conditioning (HVAC) system called BeCool. This system integrates natural gas-based electricity generation using a fuel cell, waste heat storage, and conversion of stored thermal energy into air conditioning by varying the concentration of a liquid desiccant solution. An internal combustion engine or a microturbine could be substituted for the fuel cell, if desired. In the BeCool system the waste heat produced from continuous power generation is used to increase the concentration of a liquid desiccant solution. The concentrated liquid desiccant solution is then stored. When air conditioning is required, the high concentration solution is used to dehumidify an air mixture of outside air (OA) and return air (RA). The dehumidification process is cooled indirectly by outside air subjected to evaporative cooling inside the same device. The temperature of the dehumidified process air is subsequently reduced using dew point-style indirect evaporative cooling. In this process, a portion of the dehumidified air (DA) is separated from the bulk air and subjected to evaporative cooling as it flows countercurrent to the bulk process air. This cools the bulk process air, which is then supplied to the building at low temperature and low humidity. The low concentration liquid desiccant created by the dehumidification process is stored and eventually regenerated to a high-concentration state using the waste heat from power generation. Dehumidification and air cooling is achieved without any vapor compression and without any greenhouse gas-producing refrigerant.

BeCool technology solves the issue of disparate duty cycles between power generation and air conditioning. Air conditioning in a building is typically controlled using a thermostat and has a binary on/off operation. The cycling of the air conditioning system depends on interior building loads and weather. On the other hand, power generation can be continuous in a building. By storing the waste heat from power generation in a way that results in air conditioning, the system is storing heat that is then transformed into an electrical equivalent output. The integration of continuous power production, thermal energy storage, and a highly efficient heat-to-air conditioning process results in a highly efficient distributed power and HVAC process.

For this small business voucher (SBV) cooperative research and development agreement (CRADA), Be Power Tech designed and built an experimental prototype BeCool system. This system integrated a $2.5 \mathrm{~kW}$ solid oxide fuel cell system, a boost natural gas burner, and a custom made enhanced liquid desiccant air conditioner (ELD-AC) designed to produce from 2.5-tons $\left(8.8 \mathrm{~kW}_{\text {th }}\right)$ to 4 -tons $\left(14.0 \mathrm{~kW}_{\text {th }}\right)$ of cooling. This system was delivered to Oak Ridge National Laboratory (ORNL) where it was tested under multiple outdoor air conditions. The tests recorded steady state operation of the system and quantified the steady state efficiency of the system. From the steady state efficiency, the efficiency of the system associated with daily operation under multiple duty-cycles and varying weather can be inferred.

\section{BECOOL TECHNOLOGY BACKGROUND}

Be Power Tech is commercializing BeCool, the first electricity producing HVAC system; a nonvapor compression cycle, packaged rooftop unit that produces base load electricity and HVAC. The Company first plans to commercialize a 5 -ton $/ 5 \mathrm{~kW}$ BeCool. Each unit eliminates $\sim 10 \mathrm{~kW}$ 
of peak electrical demand, generates up to $43 \mathrm{MWh} / \mathrm{y}$, and saves roughly $10 \mathrm{MWh} / \mathrm{y}$ of electricity that would have been used to run a conventional AC. BeCool is scalable from 2 to 20 tons and is applicable to $98 \%$ of US commercial buildings.

The current state of the electricity-producing HVAC is TRL-5 following the testing of the prototype at ORNL.

\subsection{DESCRIPTION OF OPERATING PRINCIPLE}

Figure 1 provides a general and simplified description of BeCool technology operation. The prototype BeCool system operates using a fuel cell system and a burner to transform natural gas into electricity and heat. The heat generated is used to increase the concentration of a $\mathrm{LiCl}$ solution to $42 \%$ (mass fraction). This process occurs within a heat and mass exchanger (HMX) for liquid desiccant regenerator (HMX1). The high concentration $\mathrm{LiCl}$ is stored in a tank. When air conditioning is required, the high concentration $\mathrm{LiCl}$ is used to dehumidify process air (PA) within a dehumidifier (HMX2). PA for this prototype system is generally composed of a mixture of 30\%-40\% outdoor air (OA) with the remainder being return air (RA). The HMX2 is composed of a series of plates designed so that PA and high concentration $\mathrm{LiCl}$ flows on one surface. The $\mathrm{LiCl}$ is separated from the PA by a selectively permeable membrane that enables the interaction of water (in vapor form) with the air but prevents the flow of $\mathrm{LiCl}$ into the air. Because the liquid desiccant is at a high concentration, it will remove water from the air to reach water vapor pressure equilibrium with the air. This process, if adiabatic, would be constant enthalpy dehumidification, and therefore result in a significant temperature increase in the process air. On the opposite side of the HMX2 plates, OA flows in cross-flow to the PA. The plate prevents both streams from mixing but enables heat transfer between the two flows. Water is also flowed on the surface of the OA side of the plate. The OA in HMX2 absorbs the water, and this evaporation process (as well as sensible heat exchange with the air) cools the liquid desiccant dehumidification process on the other side of the plate. Consequently, the PA leaving HMX2 has a humidity that corresponds to a design dew point temperature, and a dry bulb temperature that is sometimes slightly higher than the inlet air temperature but far lower than it would be if the dehumidification was constant-enthalpy (the exit temperature can be slightly lower than inlet temperature if the outdoor conditions are very dry, which yields high-powered evaporative cooling).

To reduce the temperature of the PA down to supply air (SA) conditions, the stream is subjected to dew point-style indirect evaporative cooling (IEC) in a heat and mass exchanger (HMX3). HMX3 is composed of a series of plates. The entire PA flows over the plate's surface. However, at the exit of the plate approximately $30 \%-40 \%$ of the PA is redirected to flow counterflow to the bulk PA flow through HMX3, on the opposite side of the plates as the bulk PA flow. On this side of the plate water is flown, causing the redirected flow to cool to its wet bulb temperature. The redirected air flow leaves at close to $100 \%$ relative humidity (RH) and is exhausted. This reverse flow both cools the bulk flow, and is derived from the bulk flow, which means the lowest temperature achievable is the incoming air's dew point temperature, instead of its wet bulb temperature. At the outlet end of HMX3 plates, where a portion of the flow reverses its path, the exhaust air will indirectly cool the bulk air toward the exhaust air's wet bulb temperature. The cooler bulk air now has a lower wet bulb temperature, and it subsequently becomes the next batch of exhaust air, lowering the achievable temperature further. This continues until it cannot 
continue further, which (in theory) is when the dry bulb temperature of the bulk air equals the wet bulb temperature of the exhaust air, which, since they are the same stream, occurs when the bulk process air is exiting at its dew point. The bulk PA exiting HMX3 is the SA to the building.

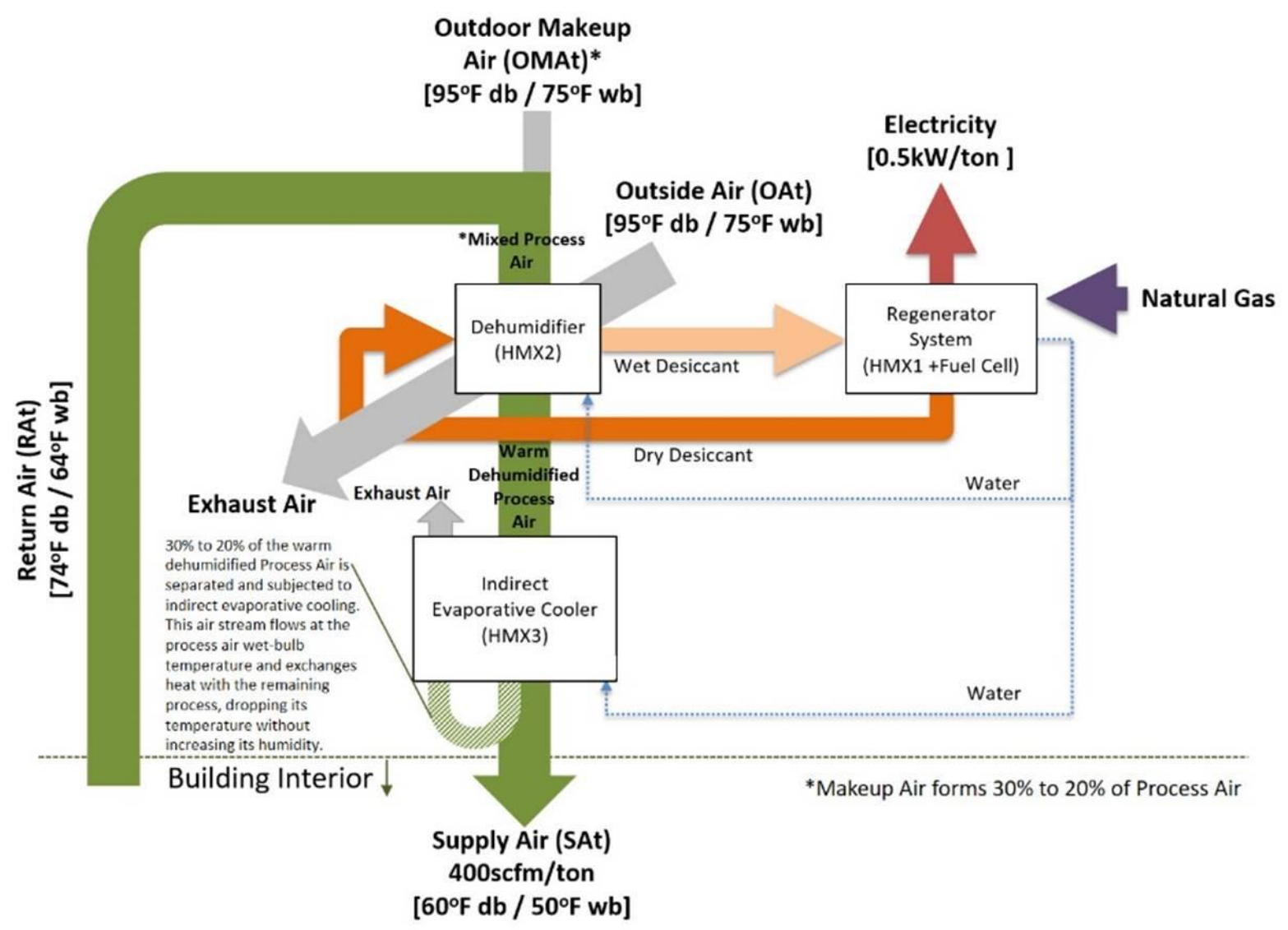

Figure 1. BeCool system general operating diagram. [Air temperatures and humidity points shown are for exemplary reference and do not correspond to test results]

\subsubsection{A More Effective Cooling Process}

The air conditioning process described is generally referred to as enhanced liquid desiccant air conditioning (ELD-AC). ELD-AC typically requires lower enthalpy removal from the air for the air to achieve the same change in conditions, as compared to a VCC.

The heat-driven process controls the more energy intensive latent cycle first, followed by sensible indirect evaporative cooling using water extracted from the air. The change in enthalpy is roughly $30 \%$ lesser than vapor compression (Figure 2). Most VCC systems introduce air into the space at $100 \% \mathrm{RH}$ and at a temperature much lower than for human comfort. VCC systems rely on heat from occupants and from building equipment (and sometimes supply their own reheat) to heat up the air to a point of comfort. Consequently, the prevailing method of air conditioning, VCC, is energy intensive and uncomfortable at times. 


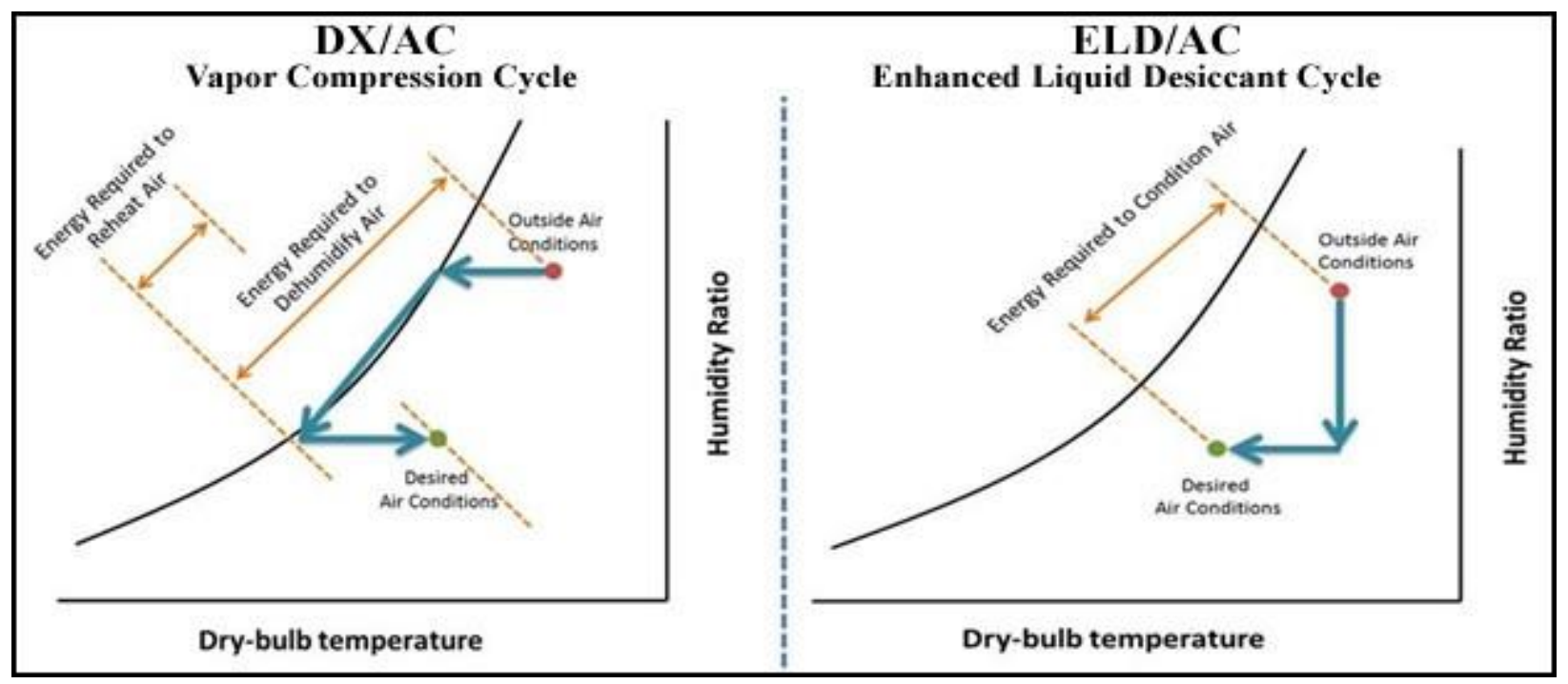

Figure 2. Difference in air conditioning process between a vapor compression cycle (VCC) and an enhanced liquid desiccant evaporative cooling air conditioner (ELD/AC) cycle.

The ELD-AC dehumidification process is achieved through diffusion of water vapor from the air across a semipermeable membrane into a flowing liquid of high concentration liquid desiccant. Liquids cannot penetrate the membrane, so the desiccant is isolated from the conditioned air stream. This process of dehumidification is actively cooled using outside air so that it does not increase the DA temperature (however, even if it did, this would not increase the overall maximum enthalpy change performed, as long as the dehumidification process does not yield an increase in enthalpy). Air dehumidification is often the most energy intensive portion of an air conditioning process, so most of the energy is removed from the air through the heat-driven dehumidification process. The ELD-AC process then cools the dry warm air using a novel method of indirect evaporative cooling.

\section{STATEMENT OF OBJECTIVES}

The SBV CRADA had the following objectives:

1. Develop, engineer, and fabricate a testable and fully instrumented BeCool unit

2. Test the performance of the prototype BeCool system at ORNL under multiple simulated outdoor air conditions

3. Evaluate test results to determine potential enhancements to existing technology, tradeoffs in system design, and sizing of components

\section{BENEFIT TO THE FUNDING DEPARTMENT OF ENERGY'S MISSION}

This project benefits the Department of Energy's (DOE's) Building Technology Office's (BTO's) missions of reducing building energy consumption per square feet, energy costs, and greenhouse gas emissions. 


\subsection{REDUCE BUILDING ENERGY CONSUMPTION PER SQUARE FOOT}

The BeCool air conditioning system has the potential to significantly reduce the primary energy consumption associated with commercial and residential air conditioning and heating systems. Table 1 estimates the primary energy savings technical potential (PESTP). ${ }^{1}$

Table 1. Results of primary energy savings technical potential of the BeCool technology

\begin{tabular}{lccccr} 
& Quads & & $\%$ Savings & & 2030 Energy Market Size (Quads) \\
\hline RTU Commercial AC & 0.569 & x & $185 \%$ & $=$ & 1.050 \\
Natural Gas Heater & 1.576 & x & $167 \%$ & $=$ & 2.631 \\
Electric Heater & 0.355 & x & $126 \%$ & $=$ & 0.449 \\
Total & & & & & $\mathbf{4 . 1 3 1}$ \\
\hline
\end{tabular}

Note: $\mathrm{PESTP}$ = primary energy savings technical potential;

Source: https://trynthink.github.io/scout/calculator.html

Note that in all cases the primary energy savings associated with the use of BeCool is higher than $100 \%$. This is because the by-product of the heating or cooling process is locally generated electricity, which offsets the primary energy associated with centralized electricity production. This characteristic makes BeCool a truly transformational technology from an energy savings standpoint and consequently from a financial standpoint. In most cases, greater than $100 \%$ primary energy savings translates to profitable operation (i.e. the market value of the output, air conditioning and electricity, is higher than the market value of the input, natural gas).

\subsubsection{Primary Energy Savings Technical Potential (PESTP) Calculation}

The BeCool technology produces heat, electrical power, and air conditioning (Figure 3). The system competes favorably with commercial rooftop air conditioners (RTU Commercial AC), which are electricity driven; with natural gas heaters; and with electric heaters.

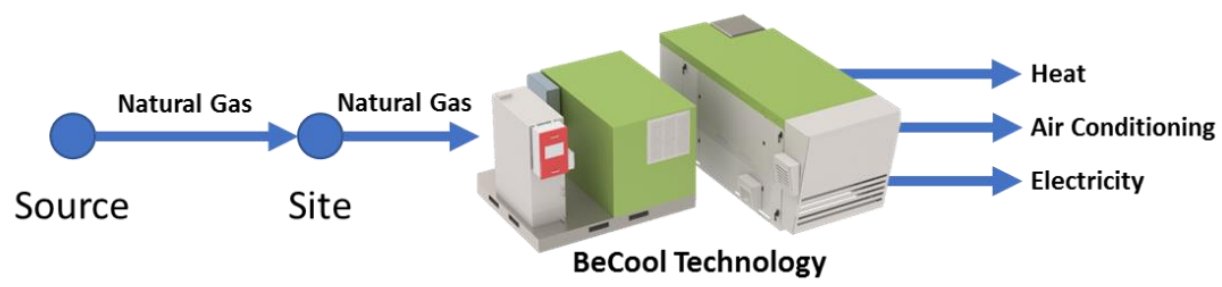

Figure 3. General conversion of primary energy to final energy products for the BeCool technology.

\subsubsection{Calculation of Primary Energy Consumption of BeCool System}

The BeCool system uses site natural gas energy. Using the PESTP method, the site natural gas energy is converted to source natural gas energy by multiplying it by 1.09 . Site electricity conversion to primary energy uses 3.06 multiplier. $^{2}$

\footnotetext{
${ }^{1}$ DE-FOA-0001632, 2017, Building Buildings Energy Efficiency Frontiers and Innovation Technologies, Appendix F.

${ }^{2}$ Based on electricity-related losses in the 2013 Annual Energy Outlook, residential data table A4.
} 
The primary energy consumption of the BeCool system $\left(P E_{B e C o o l}\right)$ is:

$$
P E_{\text {BeCool }}=F \times 1.09-E \times 3.06,
$$

where $F$ is the site natural gas energy consumption of the BeCool unit, and $E$ is the electricity produced by the unit. Note that if the unit electricity production has a higher efficiency than that of the grid, $P E_{B e C o o l}$ will be negative.

The average 1 st law efficiency $\left(\eta_{1 \text { st law }}\right)$ achieved by the prototype BeCool unit tested under this CRADA was 0.9 . Fuel cell electrical efficiency was $47 \%$ and fuel cell system combined heat and power efficiency was $90 \%$. This measured performance, $P E_{B e C o o l}$ per ton, operated at steady state and integrated with a fuel cell system that produces sufficient heat to sustain the air conditioning load, would be:

$$
\frac{P E_{\text {BeCool }}}{C}=\frac{\left[1.09-3.06 \eta_{F C}\right] \times 3.861}{\eta_{1 \text { st law }}-\eta_{F C}}=-3.13 \mathrm{~kW} / \text { ton }
$$

As a heating system $P E_{B e C o o l}$ would be the same as for a fuel cell combined heat and power system:

$$
\frac{P E_{B e C o o l}}{H}=\frac{\left[1.09-3.06 \eta_{F C}\right]}{\eta_{C H P}-\eta_{F C}}=-0.81 \mathrm{~kW} / \mathrm{kW}
$$

\subsubsection{Primary Energy Consumption of Commercial RTU AC}

A conventional commercial RTU AC uses electricity to condition air using a vapor compression system. Vapor compression cycle (VCC) systems exhibit very high energy conversion efficiencies. The coefficient of performance of the VCC $\left(C O P_{V C C}\right)$ ranges between 2.5-4.0. Thus, the primary energy consumption of the RTU is measured in terms of $\mathrm{kW} /$ ton and is defined as

$$
P E_{R T U}=3.06 \times E
$$

and

$$
\frac{P E_{R T U}}{C}=\frac{3.06 \times 3.861}{C O P_{V C C}} .
$$

This would range between 4.7 and 3.0, for a $C O P_{V C C}$ between 2.5 and 4.0, respectively. For an average system with $C O P_{V C C}$ equal to 3.2 , the primary energy consumption of the RTU would be $3.7 \mathrm{~kW} /$ ton.

\subsubsection{Primary Energy Consumption of Natural Gas Heaters}

Conventional natural gas heaters use site natural gas to create heat directly through combustion. The heat recovery efficiency of the burner $\left(\eta_{\text {burner }}\right)$ dictates the primary energy consumed by the system $\left(P E_{N G H}\right)$. High-efficiency natural gas heaters have $\eta_{b u r n e r}$ of about $90 \%$. Using equation (6), the $P E_{N G H}$ of these systems is

$$
\frac{P E_{N G H}}{H}=\frac{1.09}{\eta_{\text {burner }}} \approx 1.21 \mathrm{~kW} / \mathrm{kW}
$$




\subsubsection{Primary Energy Consumption of Electric Heaters}

Electric heaters convert site electricity to heat through a resistive element. Since $100 \%$ of the electricity used is converted to heat, the primary energy consumption of electric heaters $\left(P E_{E H} /\right.$ $H$ ) is $3.06 \mathrm{~kW} / \mathrm{kW}$.

\subsubsection{Primary Energy Savings Calculation}

Table 2 provides a summary of the primary energy consumption and potential savings of the BeCool system.

Table 2. Primary energy savings of BeCool technology

\begin{tabular}{lccc}
\hline & $\begin{array}{c}\text { Heating } \\
(\mathbf{k W / k W})\end{array}$ & $\begin{array}{c}\text { Cooling } \\
(\mathbf{k W} / \mathbf{t o n})\end{array}$ & $\begin{array}{c}\% \\
\text { Savings }\end{array}$ \\
\hline RTU commercial AC & - & 3.7 & $185 \%$ \\
Natural gas heater & 1.21 & - & $167 \%$ \\
Electric heater & 3.06 & - & $126 \%$ \\
BeCool & -0.81 & -3.13 & - \\
\hline
\end{tabular}

Note: Percent savings yields a lower number for the more inefficient heater only because our primary energy usage is negative.

\subsection{REDUCTION IN GREENHOUSE GASES}

The BeCool technology reduces the contribution of ACs to global warming. This is accomplished by eliminating refrigerants with high global warming potential (GWP), increasing building energy efficiency, and enabling renewable energy deployment.

\subsection{ELIMINATION OF HIGH GWP REFRIGERANTS}

Virtually all air conditioning products operating in the market today use refrigerants with high GWP. For example, 410A, a widely used RTU refrigerant has a GWP of 2,088. Refrigerants are subject to leaks during production, transportation, deployment into the AC, operation, and decommissioning. Given the high GWP of modern refrigerants, a small amount released into the environment has a large effect on climate. Table 3 shows an estimate of global warming impact associated with a 5-ton RTU from refrigerant leakage.

Table 3. Estimate of GWP of conventional AC using R140A refrigerants

\begin{tabular}{lc}
\hline \multicolumn{1}{c}{ Refrigerant } & Effect \\
\hline Unit capacity (ton) & 5 \\
Refrigerant charge (lb/ton) & 4 \\
Refrigerant charge (kg/ton) & 1.8 \\
Total refrigerant charge in unit $(\mathrm{kg})$ & 9.1 \\
Refrigerant recharging rate (times/y) & 0.1 \\
Refrigerant leak rate (kg/y) & 0.9 \\
Total refrigerant used in unit lifetime $(\mathrm{kg})$ & 22.7 \\
\hline
\end{tabular}




\begin{tabular}{lc}
\hline \multicolumn{1}{c}{ Refrigerant } & Effect \\
\hline Annualized refrigerant emissions $(\mathrm{kg} / \mathrm{y})$ & 1.5 \\
GWP of refrigerant $\left(\mathrm{CO}_{2}\right.$ equivalent) & 2,088 \\
$\mathrm{CO}_{2}$ equivalent emissions (kg/y) & 3,157 \\
$\mathrm{CO}_{2}$ equivalent emissions (tons of $\left.\mathrm{CO}_{2, \mathrm{eq}} / \mathrm{y}\right)$ & 3.2 \\
\hline
\end{tabular}

\subsection{GREENHOUSE GAS EMISSION REDUCTIONS THROUGH BUILDING EFFICIENCY}

As shown in Section 4.1 the PESTP of BeCool is approximately 4.1Quads. The US greenhouse gas emissions (GHG) related to energy in 2015 was 5,259 million metric tons of $\mathrm{CO}_{2}{ }^{3}$ In 2015, the total US primary energy consumption was 97.7Quads. ${ }^{4}$ Therefore the GHG intensity of US primary energy consumption is approximately 53.8 million metric tons of $\mathrm{CO}_{2}$ per Quad. Given BeCool's PESTP, the technology has the potential to reduce 222 million metric tons of $\mathrm{CO}_{2}$.

Table 4. CO2 Emission Reduction Potential for BeCool System

\section{Carbon Dioxide Reduction Potential for the US}

Total US Energy Related GHG Emissions, 2015: 5259 million metric tons of $\mathrm{CO}_{2}$

Total US Primary Energy Consumption, 2015: $\quad 97.7$ Quads

GHG Intensity of US, 2015: $\quad 53.8$ million metric tons of $\mathrm{CO}_{2}$ per Quad

$\underline{\text { BeCool }}$

Primary Energy Savings Potential of BeCool: $\quad 4.1$ Quads

GHG Savings Potential of BeCool: $\quad 222$ million metric tons of $\mathrm{CO}_{2}$

Be Power Tech has conducted yearly performance modeling of BeCool systems using typical meteorological year weather data and building models in different locations in the United States. Figure 4 shows estimated $\mathrm{CO}_{2}$ reductions based on analysis conducted for California climate zone 7 and 14. As shown, a BeCool system operated with an internal combustion engine with $27 \%$ electrical efficiency and $90 \%$ combined heat and power efficiency would result in an average of $30 \% \mathrm{CO}_{2}$ reductions when compared to use of the local grid to power a conventional RTU HVAC. Similarly, if a 50\% electrical efficient and 90\% combined heat and power efficient fuel cell power system were used, the average $\mathrm{CO}_{2}$ emissions of the system would be $53 \%$. These reductions are significant, particularly because of California's high degree of renewable energy in its electrical mix.

\footnotetext{
${ }^{3}$ Source: US EIA, Monthly Energy Review (Oct. 2016), Table 12.1

${ }^{4}$ Source: US EIA, Monthly Energy Review (Apr. 2016), Table 1.3
} 


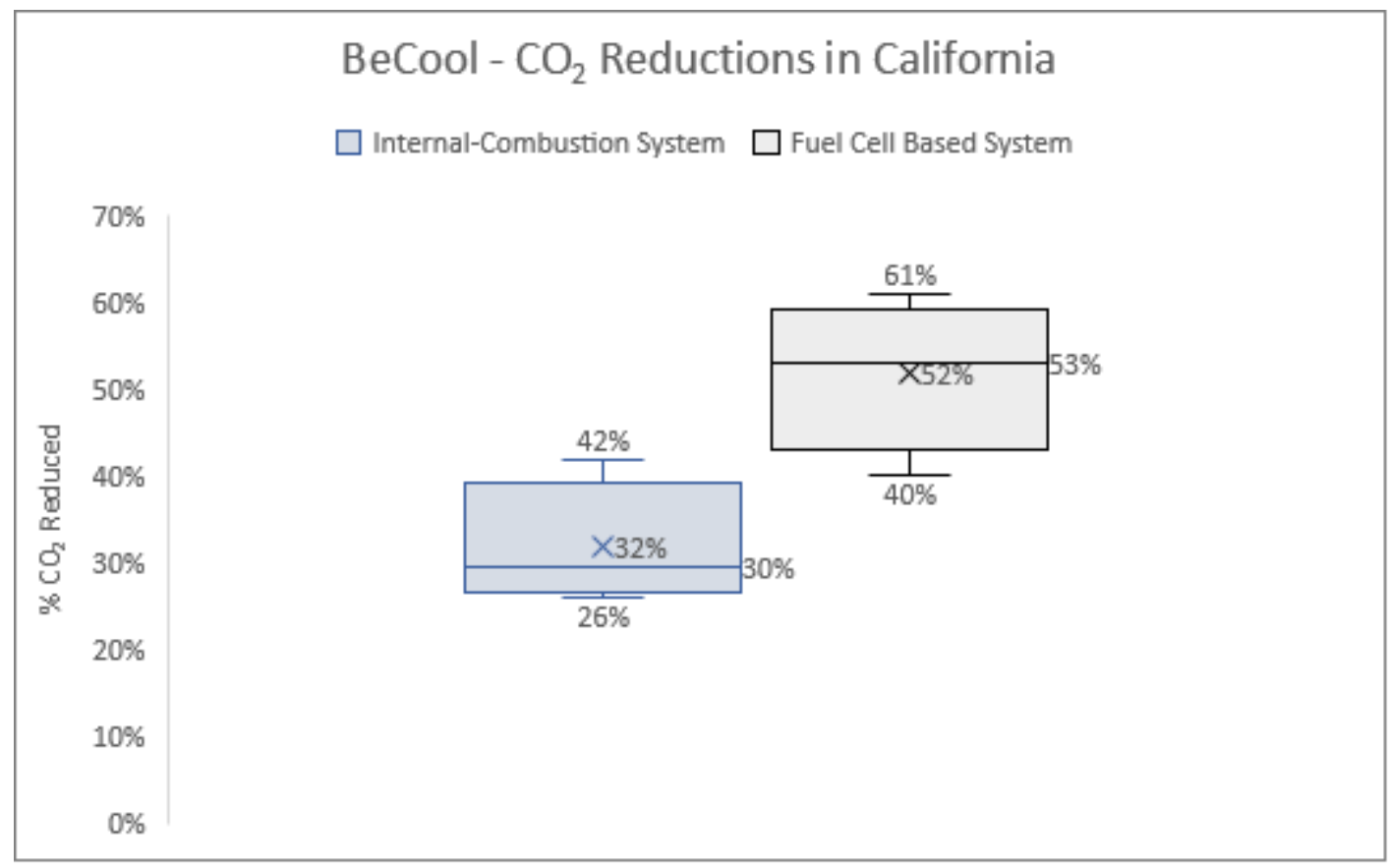

Figure 4. Results of modeling conducted by Be Power Tech shows $\mathrm{CO}_{2}$ emissions reductions of a BeCool system ranges between $26 \%-61 \%$ in comparison to conventional power generation and RTU HVAC technology.

\subsection{ENABLING INCREASED RENEWABLE ENERGY DEPLOYMENT}

BeCool enables renewable energy deployment by resolving the "duck curve" problem. ${ }^{5}$ The duck curve is a graph that illustrates the imbalance between peak electricity demand and renewable energy generation (Figure 5). As solar and wind energy generation forms a larger portion of the electric grid's primary energy mix, midday peaks can be eliminated as a result of robust solar power production. But as the sun sets, solar output decreases suddenly and leaves the grid exposed to early afternoon peaks. Because of this, grid operators must invest in energy storage systems and peaking plants. This adds to the expense of the renewable energy infrastructure and could result in reliability problems.

\footnotetext{
${ }^{5}$ The "duck curve" problem was originally referenced in the following California ISO: https://www.caiso.com/Documents/FlexibleResourcesHelpRenewables_FastFacts.pdf.
} 


\section{California hourly electric load vs. load less solar and wind (Duck Curve) for October 22, 2016}

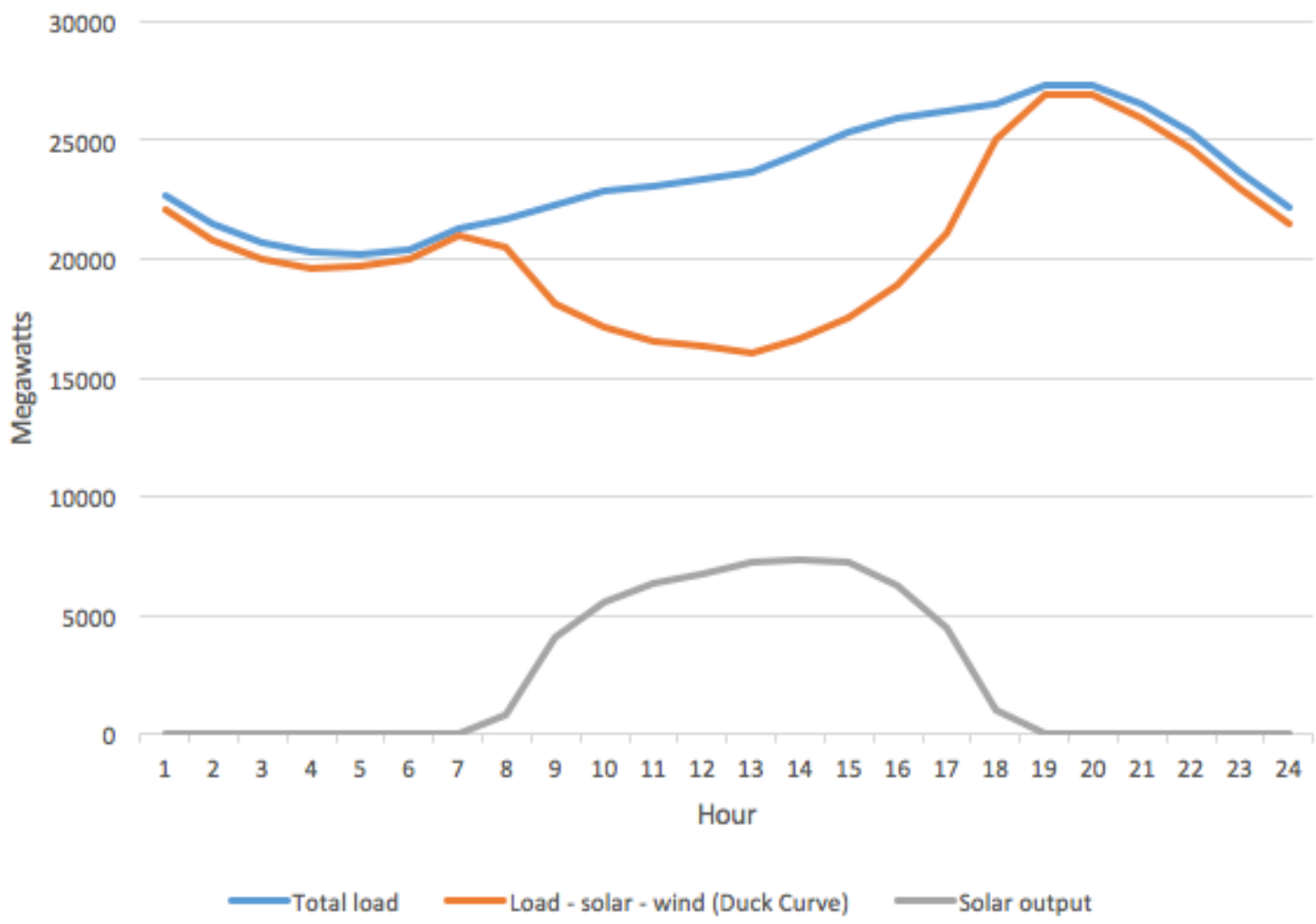

Figure 5. The duck curve. Renewable energy generation is weather and time of day dependent. The increased deployment of renewable resources like solar and wind reduces midday peak demand but leaves the grid exposed to an afternoon peak, mostly composed of building air conditioning load.

This afternoon peak demand for electricity shown in the duck curve is primarily made up by AC loads, whose usage peaks in the afternoon. BeCool shifts air conditioning load away from the electrical grid, eliminating its effect on the duck curve. This in turn reduces the cost of renewable energy deployment. Although BeCool uses natural gas, it uses it with extremely high efficiency. The comparable electrical efficiency of the BeCool system is higher than most advanced gas turbine power plants and fuel cells.

By increasing the value of the natural gas infrastructure, BeCool also improves the economics of increasing the renewable mix in the natural gas infrastructure. Renewable natural gas infrastructure has limited return on investment because of the highly seasonal nature of natural gas usage. By shifting air conditioning to the natural gas grid, investments in renewable natural gas become economically favorable. 


\section{TECHNICAL DISCUSSION OF WORK PERFORMED BY ALL PARTIES}

Be Power Tech designed and developed a fully instrumented prototype BeCool system. This system was transported to ORNL for testing (Figure 6).
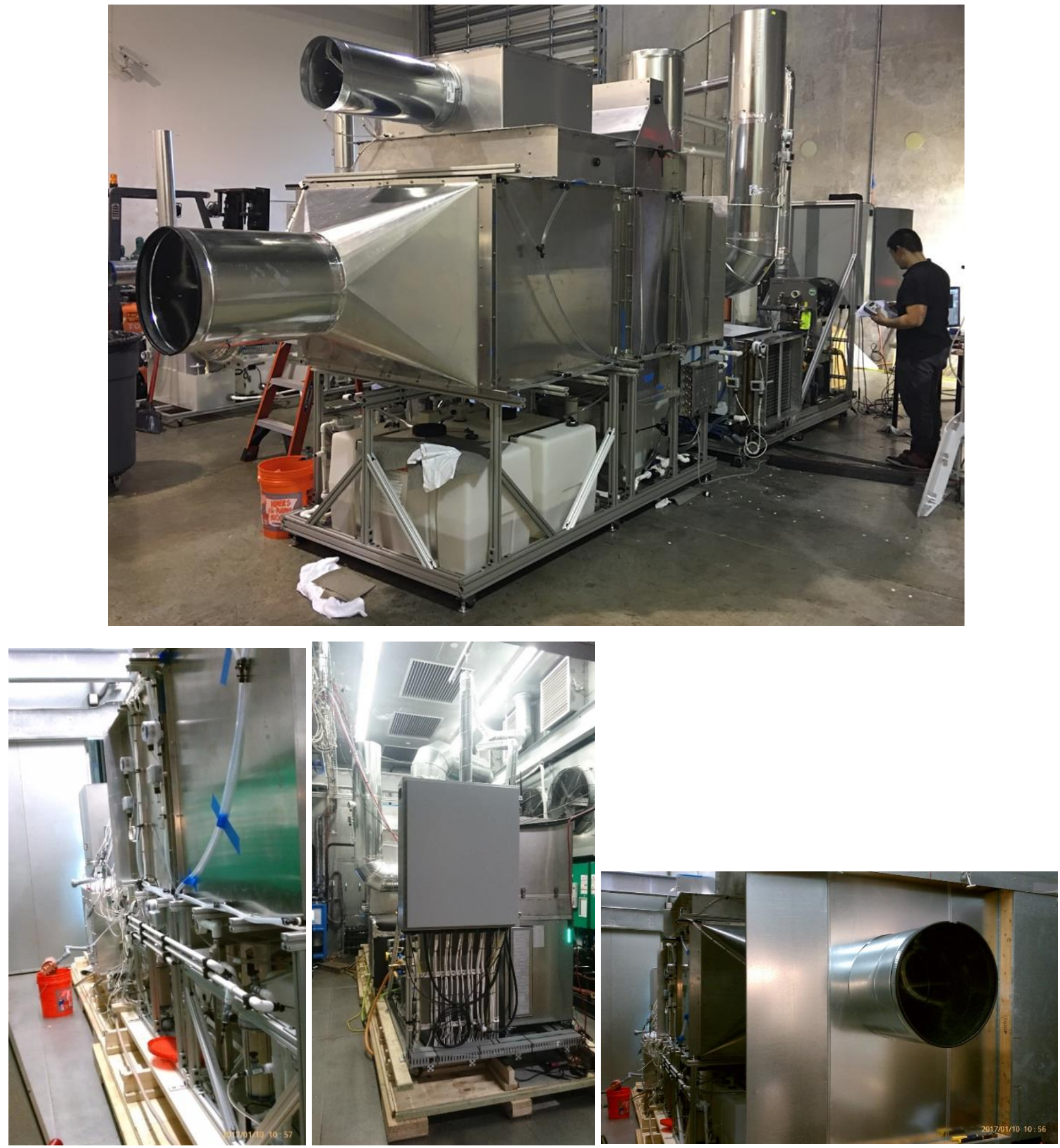

Figure 6. The BeCool prototype (top) being readied for shipment, and its installation (bottom) in the environmental chamber at ORNL.

ORNL supported Be Power Tech's testing of the prototype BeCool system. Testing was conducted using two adjoining chambers capable of simulating multiple air temperature and 
humidity conditions. One chamber was calibrated to simulate OA conditions, and the other was calibrated to simulate RA conditions. ORNL installed all necessary building integration points including electrical service, electrical load measurement, and natural gas hookup.

The major prototype subsystems consist of the heat and mass exchangers for desiccant regeneration, dehumidification, and indirect evaporative cooling and the fuel cell for power production are shown in Figure 7.

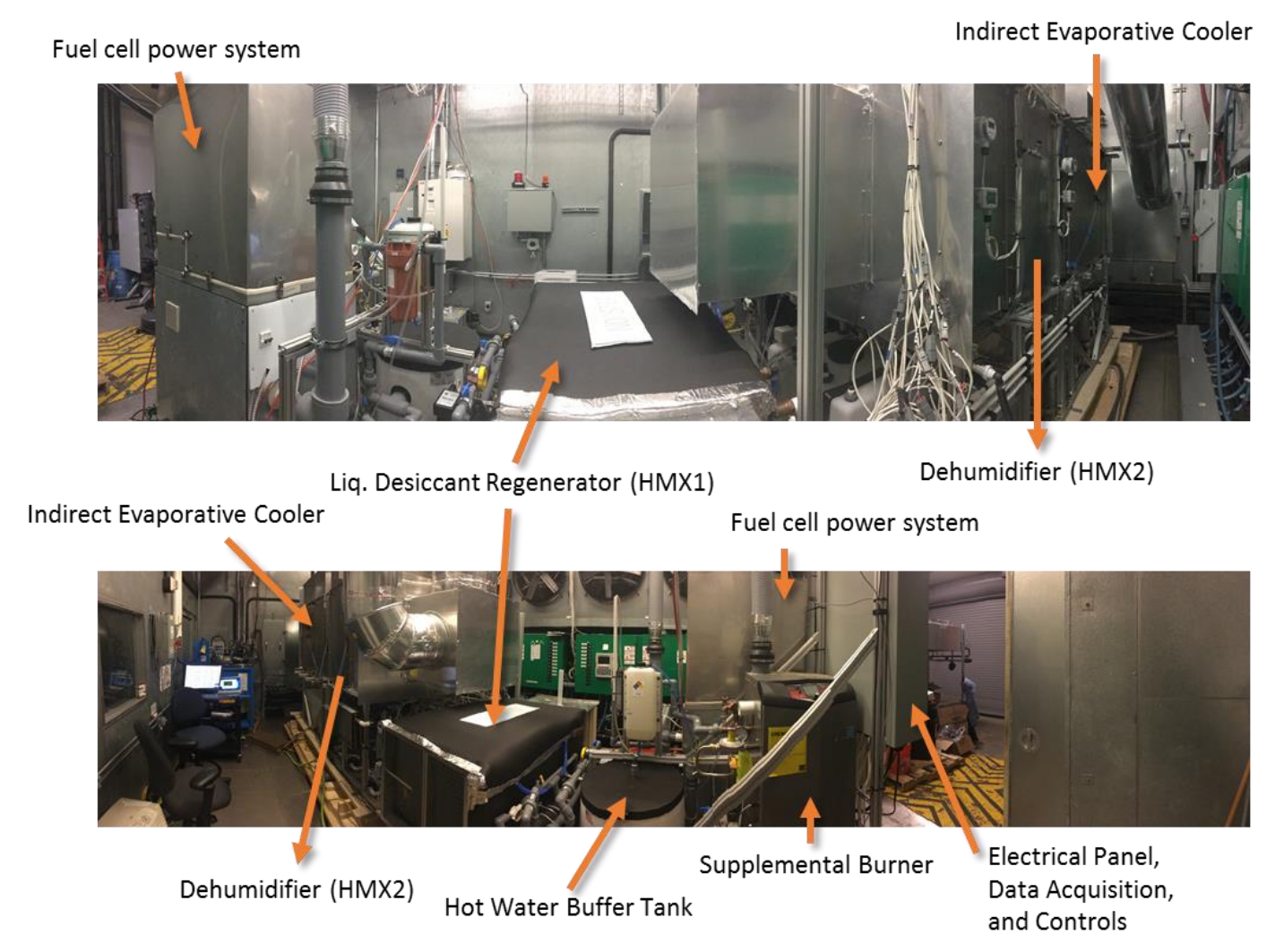

Figure 7. Major components of the BeCool prototype unit.

ORNL and the Be Power Tech team completed the following tasks:

1. Test of leaks. Two minor leaks were found, likely caused by vibration during transportation of the unit from Florida. These were fixed.

2. Test of remote control and operation from Florida.

3. Checks of valves, temperature, pressure, and flow rate readings.

4. Verification of parasitic power measurements.

5. Verification of air flow rates using an ORNL code tester.

6. Loading of $\mathrm{LiCl}$ solution. 
7. Test of evaporative cooling using the liquid desiccant (no need for fuel cell).

8. Measurement of parasitic power consumption (mainly pumps and fans).

9. Test of burner operation.

10. Test of automated messaging system in case of exhaust fan or sensor failure

11. Measurement of the higher heating value, lower heating value, and the Wobbe Index of gas supplied to the burner and fuel cell.

12. Completion of the proposed test matrix.

13. Data analysis.

14. Completion of CRADA report for DOE.

\section{SUBJECT INVENTIONS}

There were no subject inventions from this work. The primary focus of the CRADA was to obtain performance data and identify areas to further improve the efficiency of the total system. Areas of improvement are discussed in Section 11.

\section{COMMERCIALIZATION POSSIBILITIES}

The expected outcome of anticipated improvements made to the HMXs will lead to a reduction in HMX weight, size, cost, and complexity without reducing performance. This will increase the reliability of components, reduce installation costs, and decrease manufacturing setup costs. These improvements shall be accomplished while simultaneously meeting the performance targets. Be Power Tech is in negotiations with venture capitalists, leading multinational companies in the HVAC space, utility companies, and state agencies to produce and introduce their units in the United States.

\section{PLANS FOR FUTURE COLLABORATION}

ORNL, Be Power Tech, and National Renewable Energy Laboratory (NREL) have submitted a proposal to the DOE Buildings Energy Efficiency Frontiers and Innovative Technologies program that will take this technology to the next TRL level. The target is to bring the technology to the marketplace in two years. Additional leverage on making the heat and mass transfer exchangers more compact may be attained through the advanced manufacturing office and by utilizing resources in high performance computing at ORNL. These resources can enable a more compact design and faster manufacturing processes. 


\section{ANALYSIS OF TEST RESULTS}

The BeCool system was designed to provide electric power and air conditioning to buildings. Power generation occurs continuously. The process of power generation generates the heat required to regenerate the liquid desiccant. So, liquid desiccant regeneration is also a continuous process. The high-concentration liquid desiccant is stored to drive air conditioning when needed. If the rate of liquid desiccant regeneration is not sufficient to achieve the desired air conditioning (when also accounting for storage), extra heat for liquid desiccant regeneration is supplied using a burner.

While power generation is continuous, air conditioning is not, and it has a duty cycle dependent on indoor building conditions. Air conditioning is typically controlled via an on/off thermostat. When air conditioning is required, the BeCool system sends high-concentration liquid desiccant and water to the conditioning heat and mass transfer devices, HMX2 and HMX3. HMX2 dehumidifies process air, and HMX3 cools the process air to the desired SA temperature.

System performance is evaluated using the following COP and efficiency definitions.

\subsection{ST LAW EFFICIENCY}

The 1st law efficiency is calculated using equation (7):

$$
\eta_{1 \text { st Law }}=\frac{C+E}{F} .
$$

$C$ is the air cooling based on the enthalpy removed from air throughout a day; $E$ is the electrical energy produced by the system during a day; and $F$ is the chemical energy of the fuel provided to the system during a day. In this report, $F$ is calculated using the lower heating value of the fuel.

\subsection{DISTRIBUTED GENERATION EFFICIENCY}

As shown in equation (8), this efficiency is an electrical equivalent definition for a distributed energy solution:

$$
\eta_{D G}=\frac{\frac{C}{C O P V C C}+E}{F} .
$$

In this definition, $C$ is divided by the $\mathrm{COP}$ of a similar vapor compression cycle $\left(C O P_{V C C}\right)$. This definition is useful to compare the $\mathrm{BeCool}$ system with another form of onsite power generation.

\subsection{PRIMARY ENERGY COP}

The primary energy COP is calculated by equation (9):

$$
C O P_{\text {primary }}=\frac{C+E \times C O P_{V C C}}{F \times N G_{\text {primary }}} .
$$


$N G_{p r i m a r y}$ is the primary energy multiplier for natural gas (1.092). $E_{\text {primary }}$ is the primary energy multiplier for the electricity produced by the system (3.365). ${ }^{6}$ This definition treats the electricity production as potential cooling output by multiplying by $C O P_{V C C}$, to keep forms of energy consistent for a comparison between the $\mathrm{BeCool} \mathrm{system} \mathrm{and} \mathrm{a} \mathrm{vapor} \mathrm{compression} \mathrm{system.} \mathrm{For}$ comparison, a primary $\mathrm{COP}$ for a vapor compression cycle $\left(C O P_{\text {primary, } V C C}\right)$ is defined as:

$$
C O P_{\text {primary }, V C C}=\frac{C}{E_{V C C} \times E_{\text {primary }}} \approx \frac{C}{\frac{C}{C O P_{V C C}} \times E_{\text {primary }}}
$$

\subsection{RESULTS}

The testing consisted in 29 points with varying conditions in the outdoor air chamber (Figure 8 and Figure 9). The test showed a 1st law efficiency that ranged from 0.6 to 1.2. The average 1st law efficiency for all runs was 0.9 , with a standard deviation of 0.15 . Supply air temperature varied from $15.4^{\circ} \mathrm{C}$ to $19.4^{\circ} \mathrm{C}$, with an average SA temperature of $17.3^{\circ} \mathrm{C}$ and a standard deviation of $0.9^{\circ} \mathrm{C}$. SA average RH was $55 \%$, and it ranged from $48 \%$ to $62 \%$. Note that the 1 st law efficiency in this case can be greater than 1 because the heat of water vaporization is not included in this calculation.

In all cases the heat supplied by the fuel cell was not sufficient to provide the heat required to sustain the air conditioning process, since these isolated tests could not rely on storage from daily continuous regeneration. For this reason, the supplemental natural gas burner was used to supply the heat required. Fuel cell performance was very predictable and repeatable. On average the fuel cell electrochemical efficiency was $47 \%$ (lower heating value based) with a combined heat and power efficiency of $90 \%$, when producing $2.5 \mathrm{~kW}_{\mathrm{e}}$. Certain tests were performed without the fuel cell (burner only), in which case, for consistency, the expected power output and total natural gas input were calculated via the stable observed fuel cell electrical and combined heat and power efficiencies and included in the 1st law efficiency.

\footnotetext{
${ }^{6}$ Source: http://www.nrel.gov/docs/fy07osti/38617.pdf.
} 


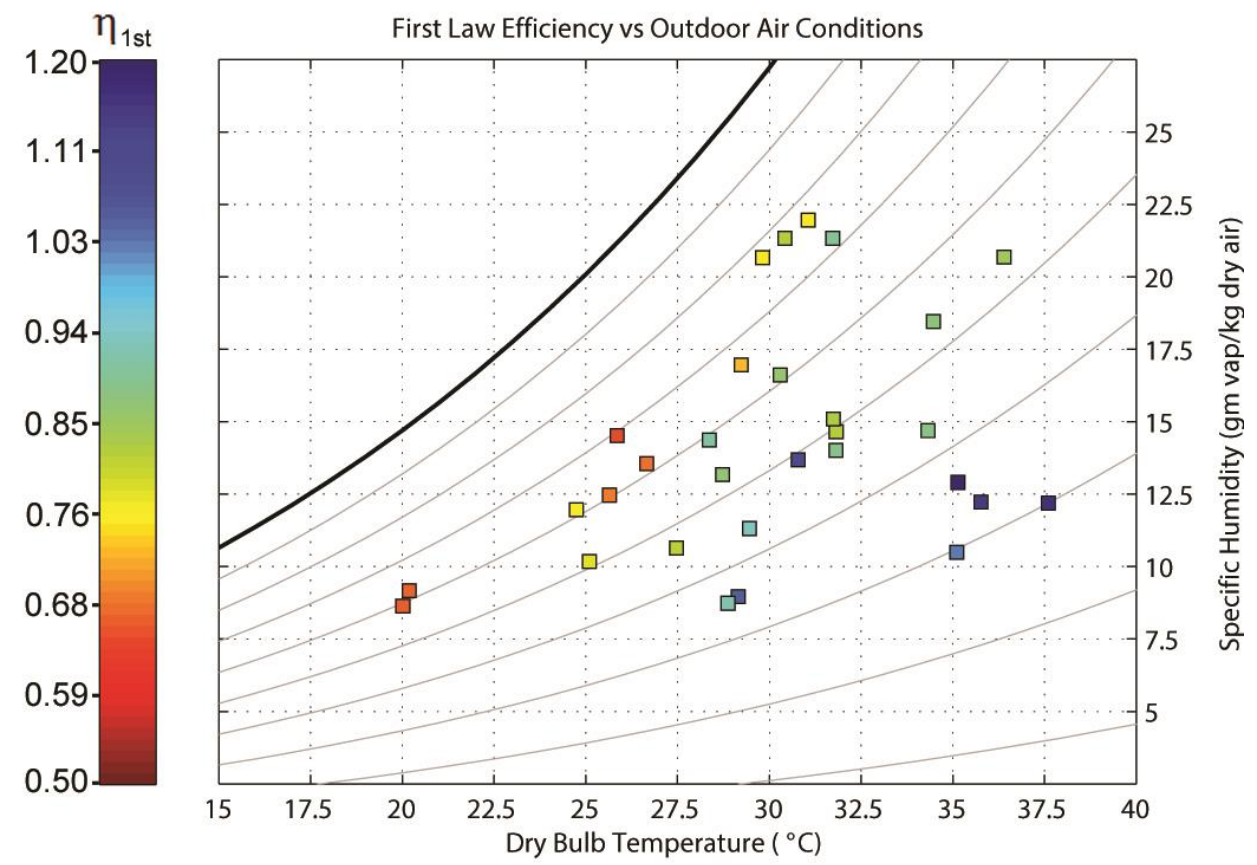

Figure 8. Summary of outdoor air tests conducted and the 1st law efficiency achieved by the BeCool system.

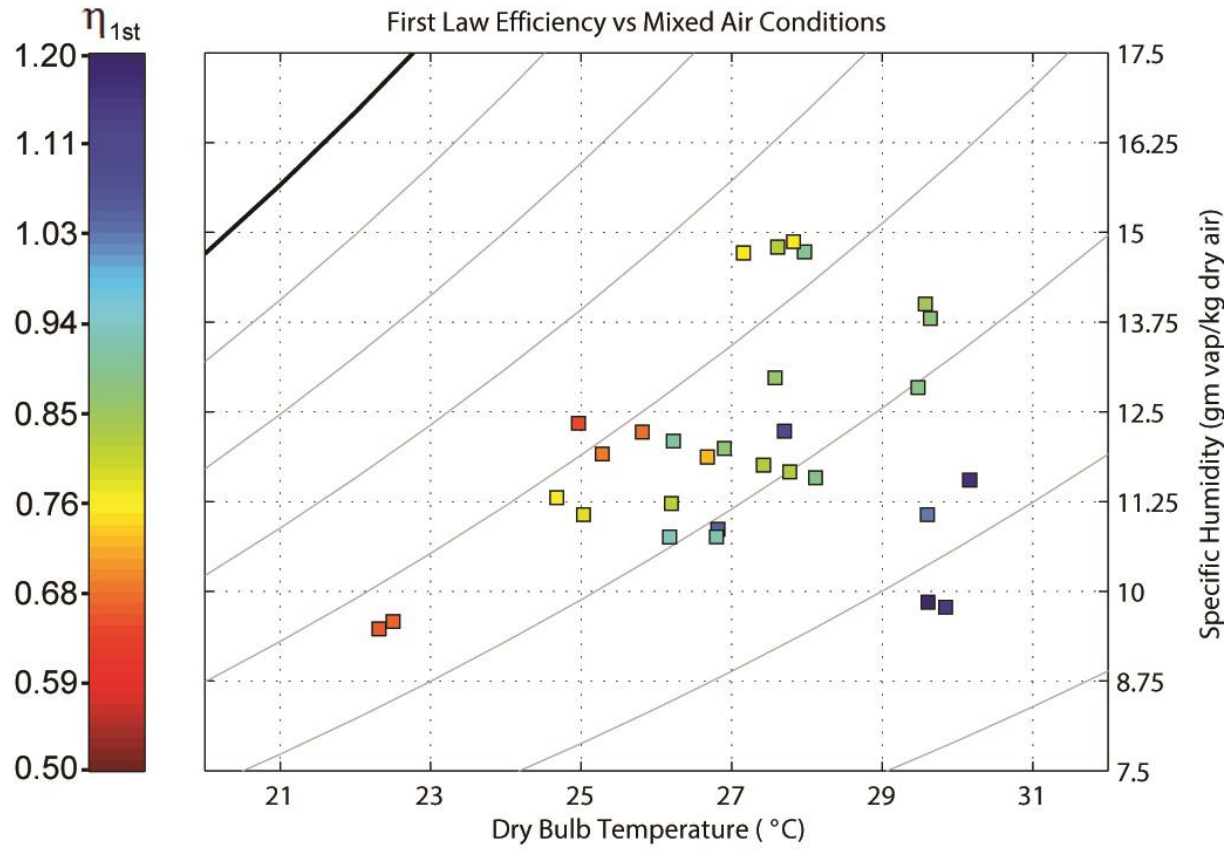

Figure 9. 1st law efficiency of prototype BeCool system.

\subsubsection{Effect of Variables on Measured $1^{\text {st }}$ Law Efficiency}

Correlation analysis shows that mixed air and OA RH had the most significant effect on $\eta_{1 \text { st Law }}$ as measured in the test under steady state conditions (Figure 10). This result makes intuitive sense, since both PA dehumidification and the subsequent process of indirect evaporative 
cooling rely on evaporative cooling. In particular, HMX2 exhibited lower than expected exhaust air flow due to channel blockages. This increased the system's susceptibility to OA humidity. The PA leaving HMX2 consistently reached the target dew point temperature, which enables HMX3 to cool the PA to the desired SA temperature. However, with the same equipment greater PA sensible cooling would have been achieved if the PA exiting HMX2 was at a lower temperature.

\section{Absolute Correlation with 1st Law Efficiency}

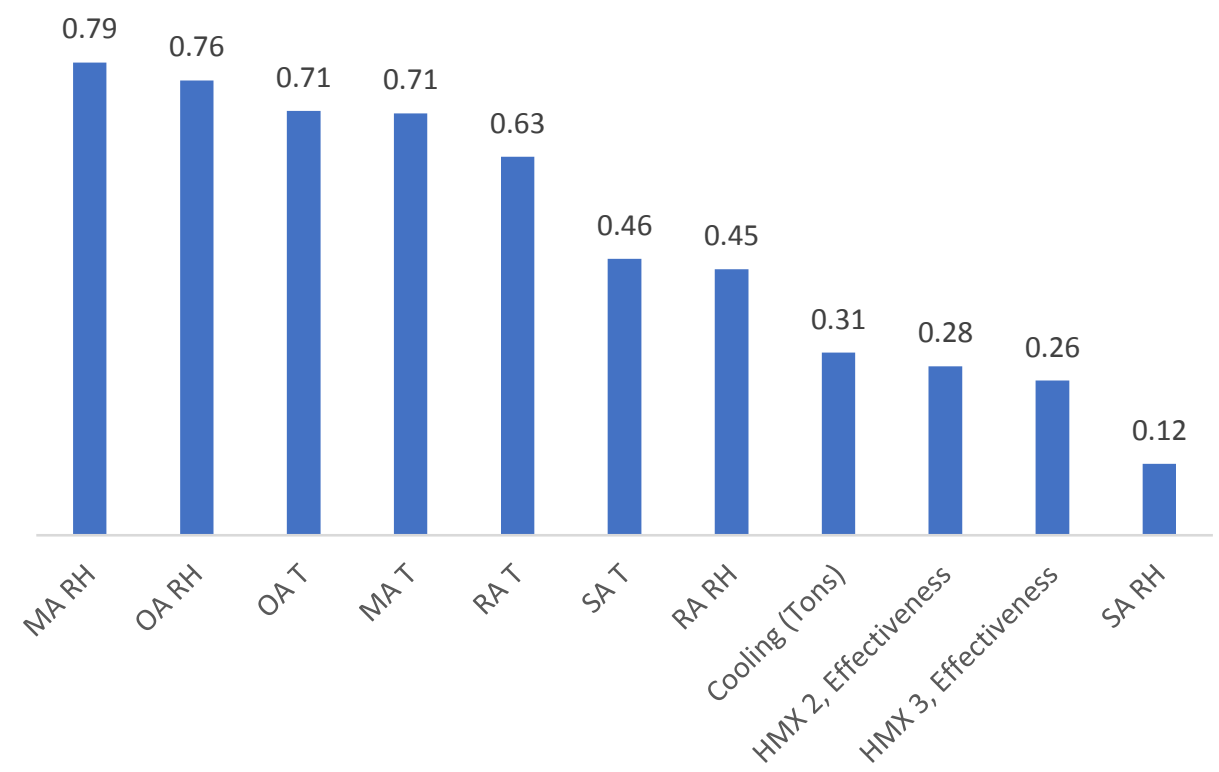

Figure 10. Sorted absolute value of correlation between input and measured test variables and 1st law efficiency measured during steady state testing.

\subsubsection{High Humidity/High Temperature Outdoor Air Results}

Tests were conducted with the following chamber conditions:

\begin{tabular}{lrr}
\hline & $\mathbf{T}_{\mathbf{d b}}\left({ }^{\circ} \mathbf{C}\right)$ & \multicolumn{1}{c}{ RH \% } \\
\hline Outdoor air & 31.7 & $72 \%$ \\
Return air & 25.1 & $56 \%$ \\
\hline
\end{tabular}

At these conditions the prototype unit provided 3.88 tons of cooling with SA conditions of $17.8^{\circ} \mathrm{C}$ dry bulb temperature and $56.1 \%$ RH (Figure 11 ).

Under these conditions the average 1 st law efficiency $\left(\eta_{1 s t}\right.$ Law $)$ was $90 \%$. 


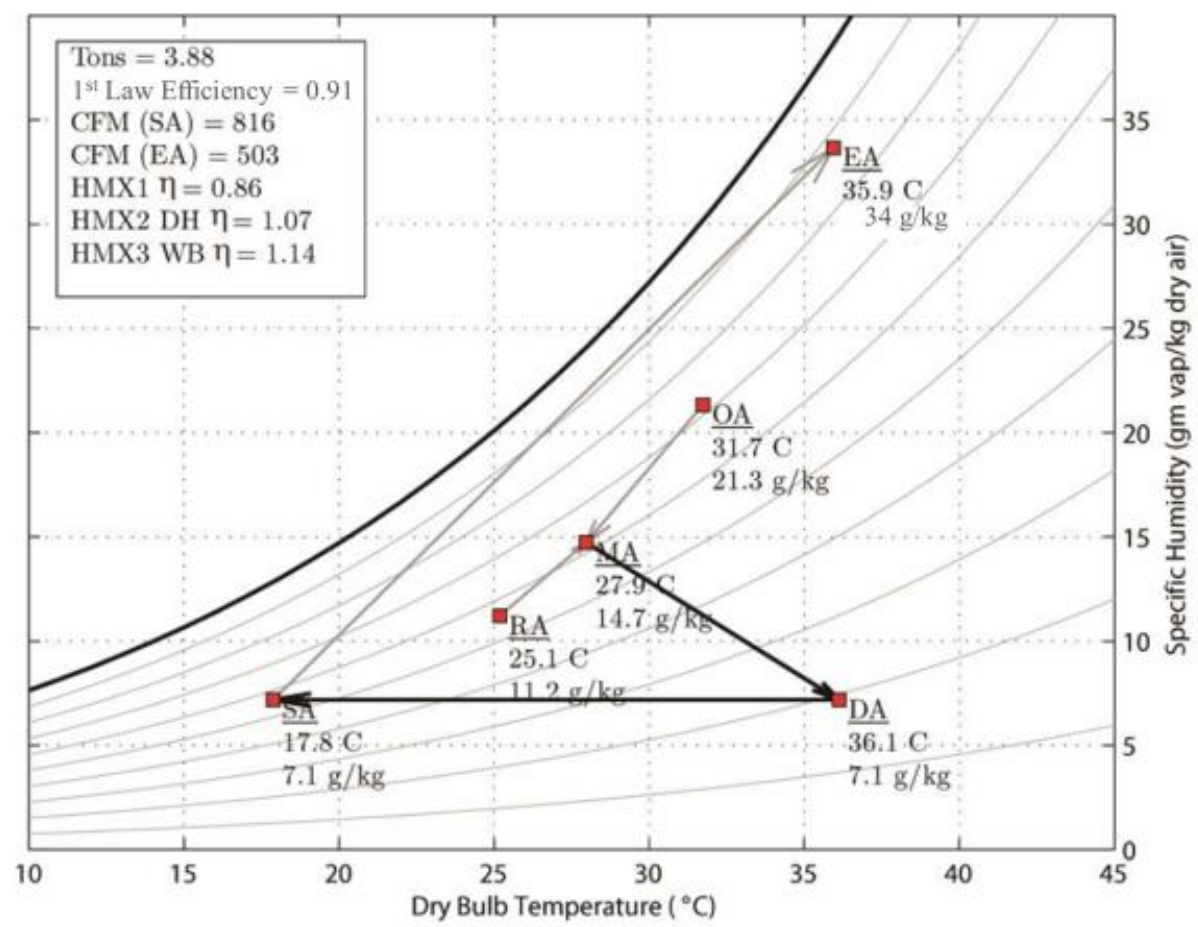

Figure 11. Psychrometric chart showing the states achieved by the prototype BeCool unit. Definitions: SA is the supply air into the building, DA is the exit airflow leaving the system dehumidifier (HMX2) and entering the indirect evaporative cooler (HMX3), OA is outside air, RA is the return air, EA is the exhaust air from HMX3, and MA is the mixed air condition at the inlet of HMX2.

\subsubsection{Performance Evaluation Accounting for HVAC Daily Duty Cycle:}

The BeCool system is designed to operate with continuous power generation and transient, on/off, air conditioning load. For this reason, an analysis of efficiency based on simulated HVAC duty cycle $(\epsilon)$ provides a better representation of performance.

For this exercise, we assume that the HVAC will be subject to the same outdoor air and return air conditions as the ones in this test. The performance of the HVAC will be identical to that measured during the test. The heat required to achieve the same performance as in the test is spread throughout the entire day. This heat is supplied by the fuel cell and by an auxiliary burner, the latter only when fuel cell heat output is not sufficient to match the performance in the test. The fuel cell system electrical efficiency ( $\eta_{\text {elec }}$ ) is $47 \%$ and combined heat and power efficiency $\left(\eta_{C H P}\right)$ is $90 \%$. Both are observed and measured efficiencies for the fuel cell system in the prototype BeCool unit. Fuel cell power electrical output is $2.5 \mathrm{~kW}$. Analysis is also conducted by simulating the de-rating of the power generator's efficiency to evaluate the use of an internal combustion engine instead of a fuel cell. For this we assumed that the internal combustion engine's electrical efficiency would be $30 \%$, that it has a combined heat and power efficiency is $90 \%$, and that it would produce $2.5 \mathrm{~kW}$ of electrical power. These efficiencies and the duty cycle are defined in equations (11)-(13): 


$$
\begin{gathered}
\eta_{\text {elec }}=\frac{\dot{E}}{\dot{F}}, \\
\eta_{C H P}=\frac{\dot{E}+\dot{H}}{\dot{F}},
\end{gathered}
$$

and

$$
\epsilon=\frac{\theta_{H V A C}}{\theta_{\text {Elec }}}
$$

$\dot{E}$ is the electrical power produced by the power generator (fuel cell or internal combustion engine), $\dot{F}$ is the lower heating value based rate of fuel chemical energy consumed by the power generator, $\dot{H}$ is the rate of recoverable waste heat from the power generator, $\theta_{H V A C}$ is the total amount of time that the HVAC system runs during the day, and $\theta_{\text {Elec }}$ is the total amount of time the power generator produces electricity during the day.

Figure 12 shows distributed energy efficiency $\left(\eta_{D G}\right)$ as a function of duty cycle $(\epsilon)$ for both an internal combustion engine and for a fuel cell engine power generator. Low $\epsilon$ results in wasted power generator heat which reduces $\eta_{D G}$. Higher $\epsilon$ results in increasing use of heat from a supplemental burner to meet the cooling load. This excess is not associated with power production and thus decreases $\eta_{D G}$.

For both the fuel cell and for the internal combustion engine, the air conditioning byproduct results in a significant increase in the perceived electrical efficiency as measured by the difference between $\eta_{D G}$ and $\eta_{\text {elec }}$.

For an $\epsilon$ of $30 \%$ the efficiency parameters are shown below:

Table 5. Efficiency calculation for BeCool system based on tested data

\begin{tabular}{lcc}
\hline \multicolumn{1}{c}{ Efficiency parameter } & Fuel cell & Internal combustion \\
\hline 1st law, $\eta_{1 \text { st Law }}$ & $87 \%$ & $79 \%$ \\
Dist. generation, $\eta_{D G}$ & $51 \%$ & $46 \%$ \\
Primary COP, COP $P_{\text {primary }}$ & 1.40 & 1.27 \\
Primary VCC COP & 0.89 & 0.89 \\
\hline Note: Assumptions assume $C O P_{V C C}$ equals 3.0. &
\end{tabular}

Note: Assumptions assume $C O P_{V C C}$ equals 3.0. 


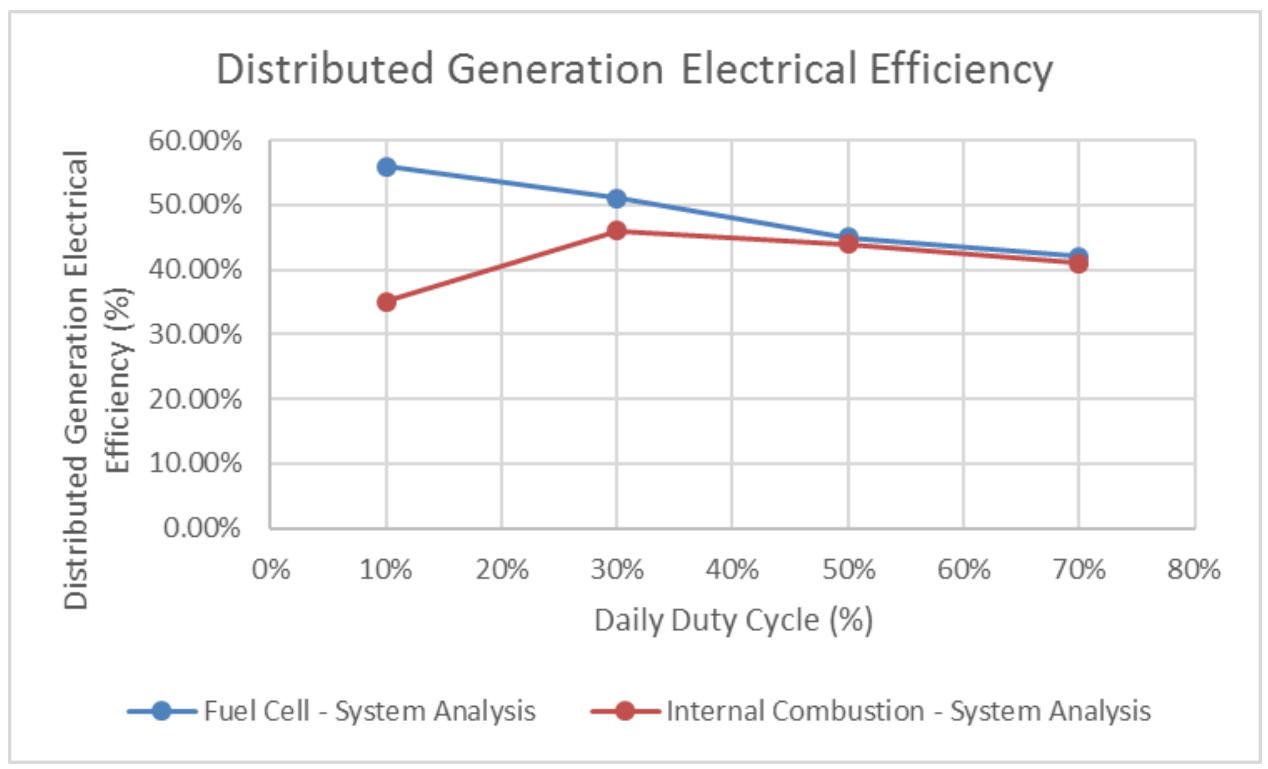

Figure 12. Distributed Generation Efficiency ( $\eta_{D G}$ ) as a function of duty cycle (€) for a fuel cell system and for an internal combustion system assuming outdoor air and SA conditions are constant.

\subsubsection{Low Humidity/High Temperature Outdoor Air Results}

Tests were conducted under the following chamber conditions:

\begin{tabular}{lcc}
\hline & $\begin{array}{c}\mathbf{T}_{\mathbf{d b}} \\
\left({ }^{\circ} \mathbf{C}\right)\end{array}$ & $\begin{array}{c}\mathbf{R H} \\
\mathbf{\%}\end{array}$ \\
\hline Outdoor air & 37.6 & $30 \%$ \\
Return air & 25.5 & $55 \%$ \\
\hline
\end{tabular}

At these conditions, the prototype unit provided 3.89 tons of cooling with SA conditions of $16.4^{\circ} \mathrm{C}$ dry bulb temperature and $54 \% \mathrm{RH}$ (Figure 13 ). Under these conditions the average $1 \mathrm{st}$ law efficiency $\left(\eta_{1 \text { st Law }}\right)$ was $126 \%$. 


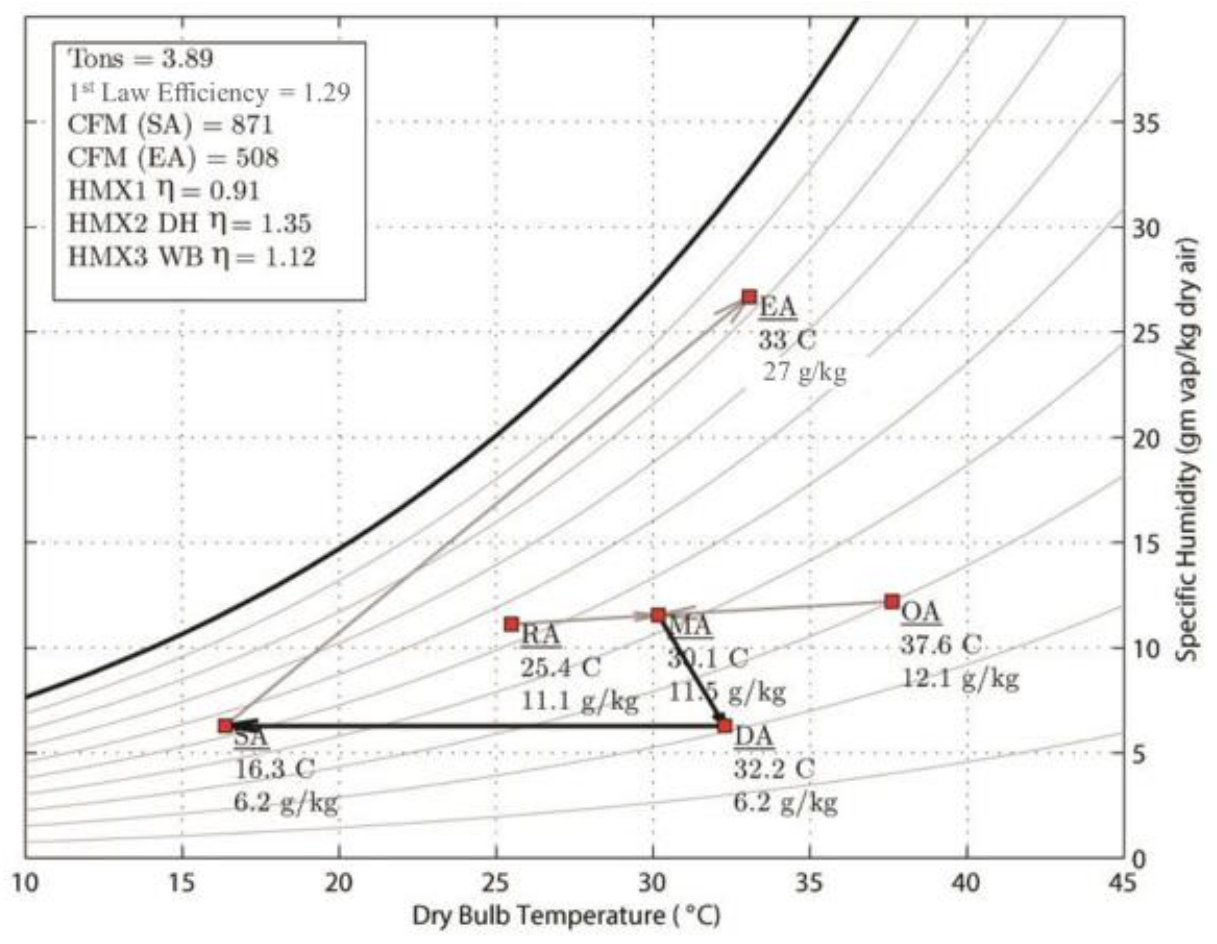

Figure 13. Psychrometric chart showing the states achieved by the prototype BeCool unit.

Definitions: SA is the supply air into the building, DA is the exit airflow leaving the system dehumidifier (HMX2) and entering the indirect evaporative cooler (HMX3), OA is outside air, RA is the return air, EA is the exhaust air from HMX3, and MA is the mixed air conditioned at the inlet of HMX2.

\subsubsection{Evaluation of HVAC Daily Duty Cycle}

Figure 14 shows distributed energy efficiency $\left(\eta_{D G}\right)$ as a function of duty cycle $(\epsilon)$ for both an internal combustion engine and for a fuel cell engine power generator. 


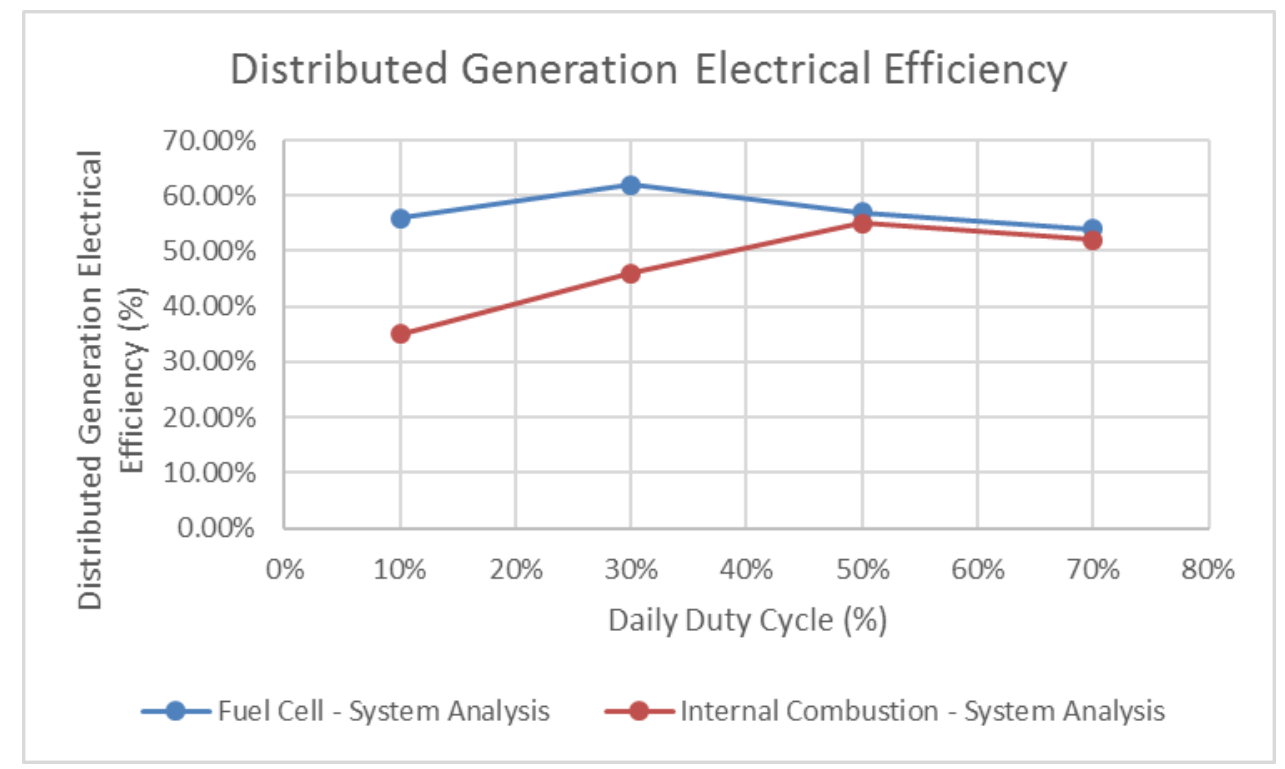

Figure 14. Distributed Generation Efficiency ( $\eta_{D G}$ ) as a function of duty cycle ( $\epsilon$ ) for a fuel cell system and for an internal combustion system assuming outdoor air and SA conditions are constant.

For both the fuel cell and for the internal combustion engine, the air conditioning byproduct results in a significant increase in the perceived electrical efficiency as measured by the difference between $\eta_{D G}$ and $\eta_{e l e c}$. For an $\epsilon$ of $30 \%$ the efficiency parameters are shown in Table 5 .

Table 6. Efficiency calculation for BeCool system based on tested data The $\mathrm{COP}_{\mathrm{VCC}}$ is assumed to equals 3.0.

\begin{tabular}{lcc}
\hline Efficiency parameter & Fuel cell & Internal combustion \\
\hline 1st law, $\eta_{1 s t \text { Law }}$ & $87 \%$ & $79 \%$ \\
Dist. generation, $\eta_{D G}$ & $51 \%$ & $46 \%$ \\
Primary COP, COP primary & 1.69 & 1.27 \\
Primary VCC COP, COP & 0.89 & 0.89 \\
\hline
\end{tabular}

\section{CONCLUSIONS}

\subsection{THE MOST EFFICIENT POWER PLANT}

The prototype BeCool system demonstrated capacity to cool and produce electricity at very high thermodynamic and comparative efficiencies. The most interesting comparative efficiency is $\eta_{D G}$ because it represents the efficiency that a natural gas powerplant must meet to have comparable performance to the BeCool system. The first order analysis shows that only the most advance combined cycle gas turbine engines or next-generation solid oxide fuel cell fuel cell systems coupled with high efficiency ACs would be able to compete with BeCool in the efficiency front. Note however that given that the ELD-AC process only requires heat, any powerplant can be enhanced with the BeCool technology. 


\subsection{THE MOST EFFICIENT AC}

The results of the testing suggest that BeCool is the HVAC technology with the highest primary energy saving potential (Figure 15).

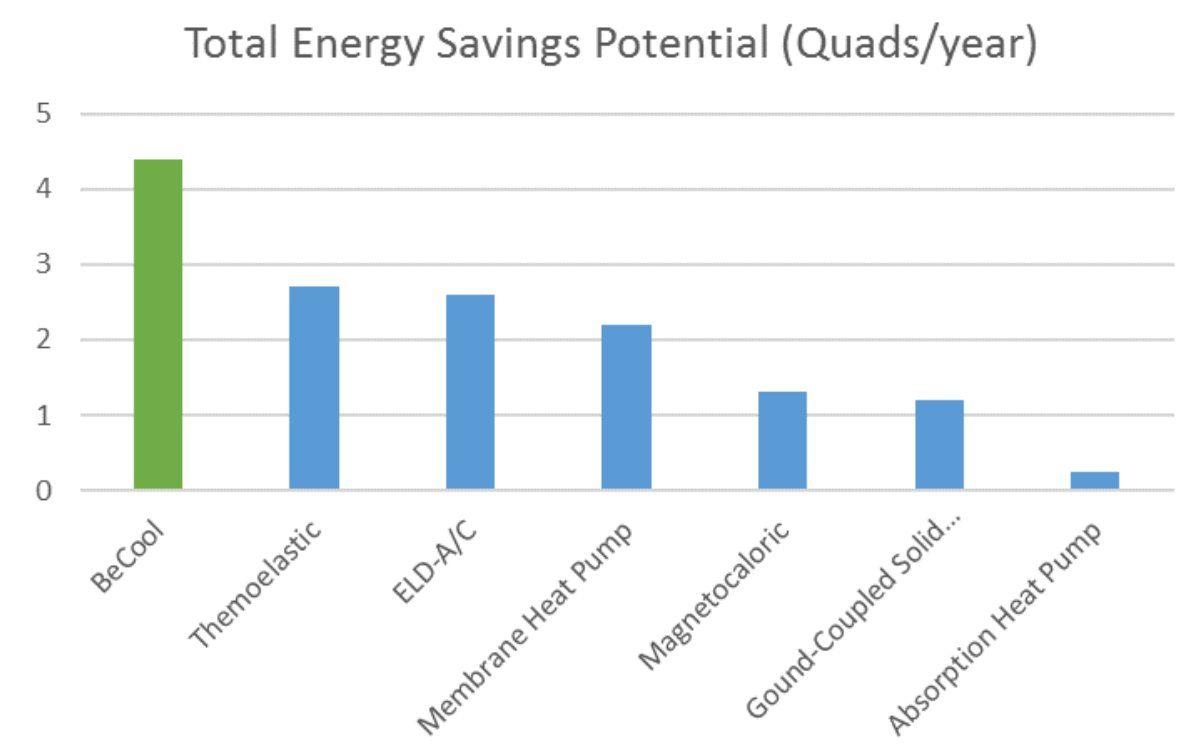

Figure 15. Primary energy savings potential of BeCool compared to other advanced air conditioning technologies. The baseline of zero is conventional vapor compression technology. ${ }^{7}$

\section{AREAS OF IMPROVEMENT}

The prototype system performed well. However, because this is only the second integrated prototype BeCool system ever built, areas of improvement were perceived. Specifically, HMX2 exhibited cooling/exhaust air blockage. These air channels are critical to reducing PA temperature in HMX2, which reduces sensible heat load in HMX3. Low performance was particularly exhibited under high-humidity, low-temperature OA conditions.

If HMX2 exhaust air flow is improved so that dehumidification is closer to isothermal, $\eta_{1 s t \text { Law }}$ could reach $130 \%$ in most of the test conditions. An alternative solution is to increase the heat transfer effectiveness of HMX3 by increasing heat transfer between the HMX3 exhaust air flow and PA.

\footnotetext{
${ }^{7}$ US Department of Energy, Building Technologies Office, September 2011, "Energy Savings Potential \& RD\&D Opportunities for Commercial Building Air Conditioning Systems," https://energy.gov/sites/prod/files/2014/07/f17/commercial_hvac_research_opportunities.pdf.
} 


\section{ACKNOWLEDGEMENTS}

This collaborative work was performed under a CRADA agreement (No. NFE-16-06126) between ORNL and Be Power Tech. The authors express their gratitude to Antonio Bouza, program manager at US DOE Building Technology Office, and the personnel at UT-Battelle, LLC Technology Transfer Office for supporting this work.

The authors also extend their appreciation to Geoff Ormston and Vishaldeep Sharma for operating the experimental chamber at ORNL. Randall Wetherington was instrumental with programming the Programming Logic Controllers and instrumentation related to operational safety. Denise Overton and Kathryn Lord assisted tirelessly with administrative tasks. 



\section{APPENDIX A. SUMMARY OF ALL TESTS PERFORMED}




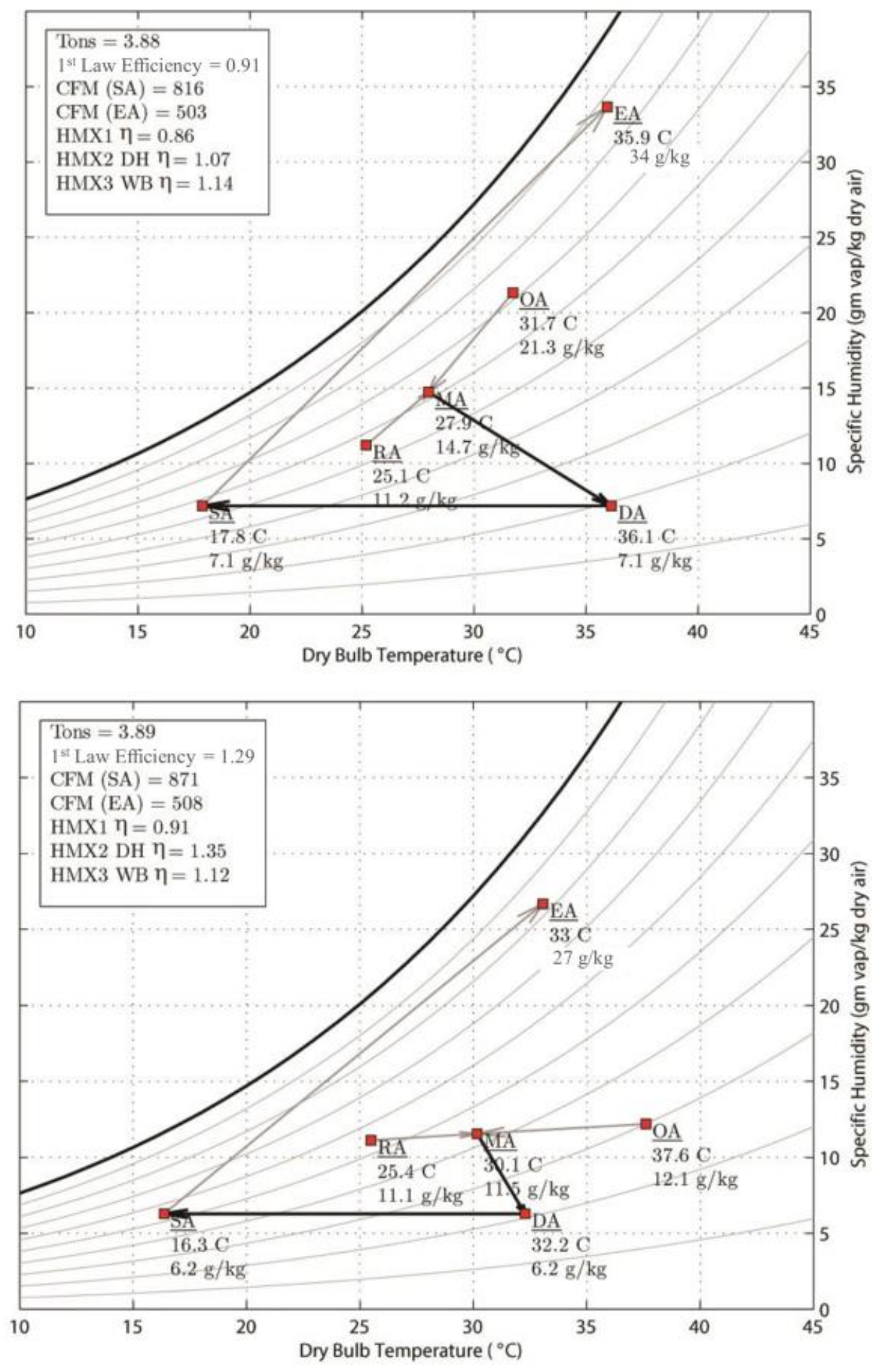

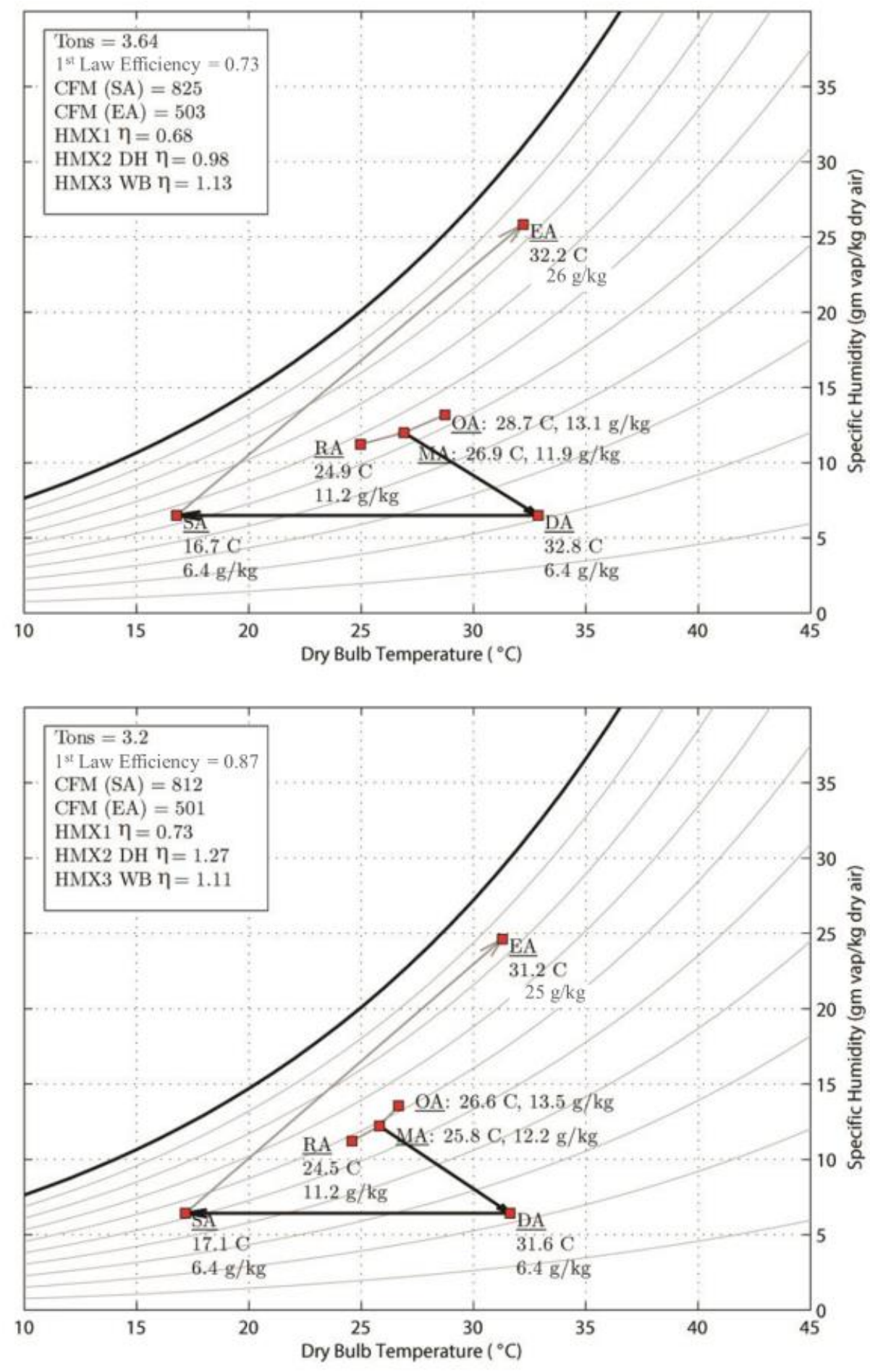

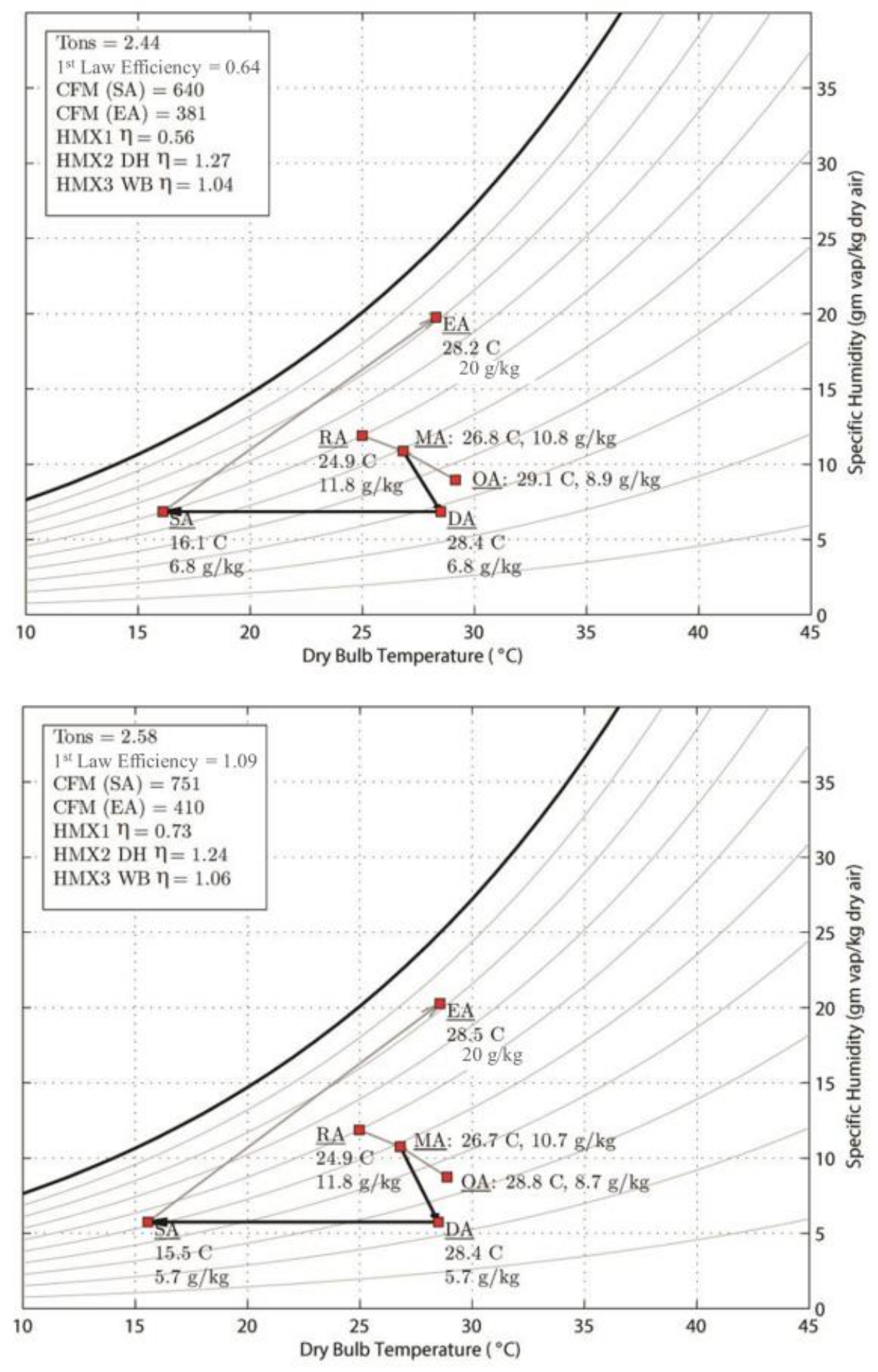

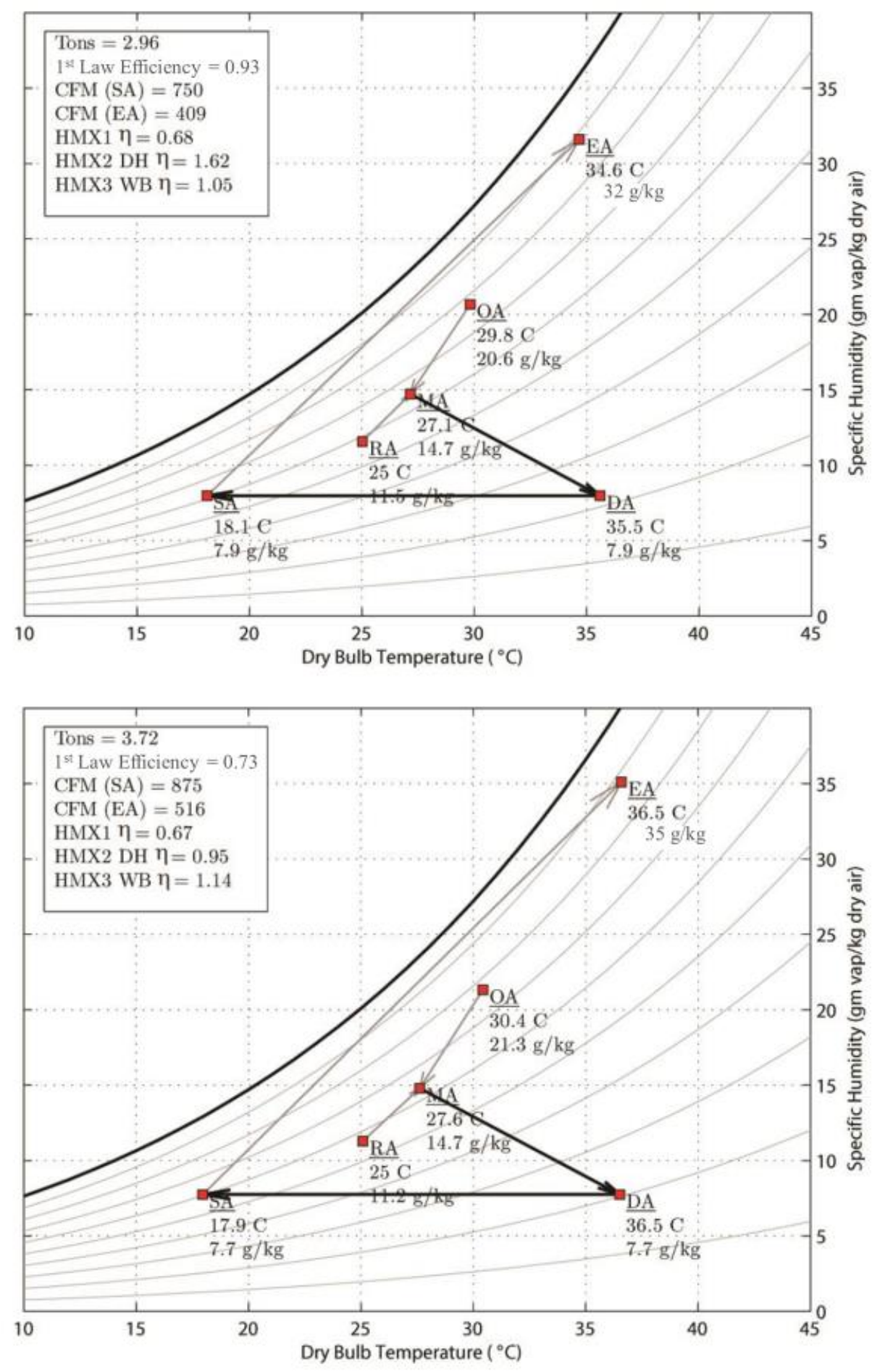

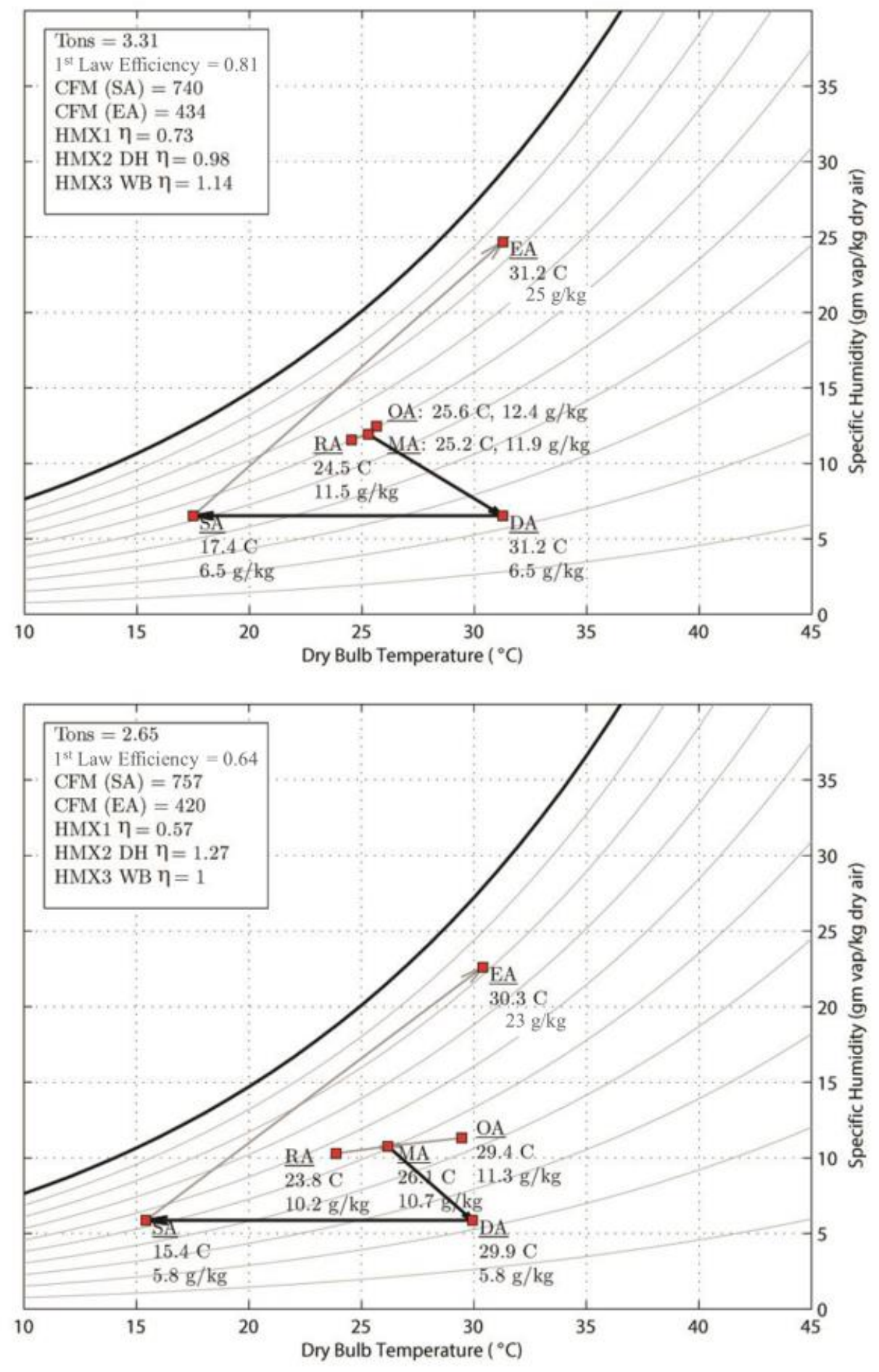

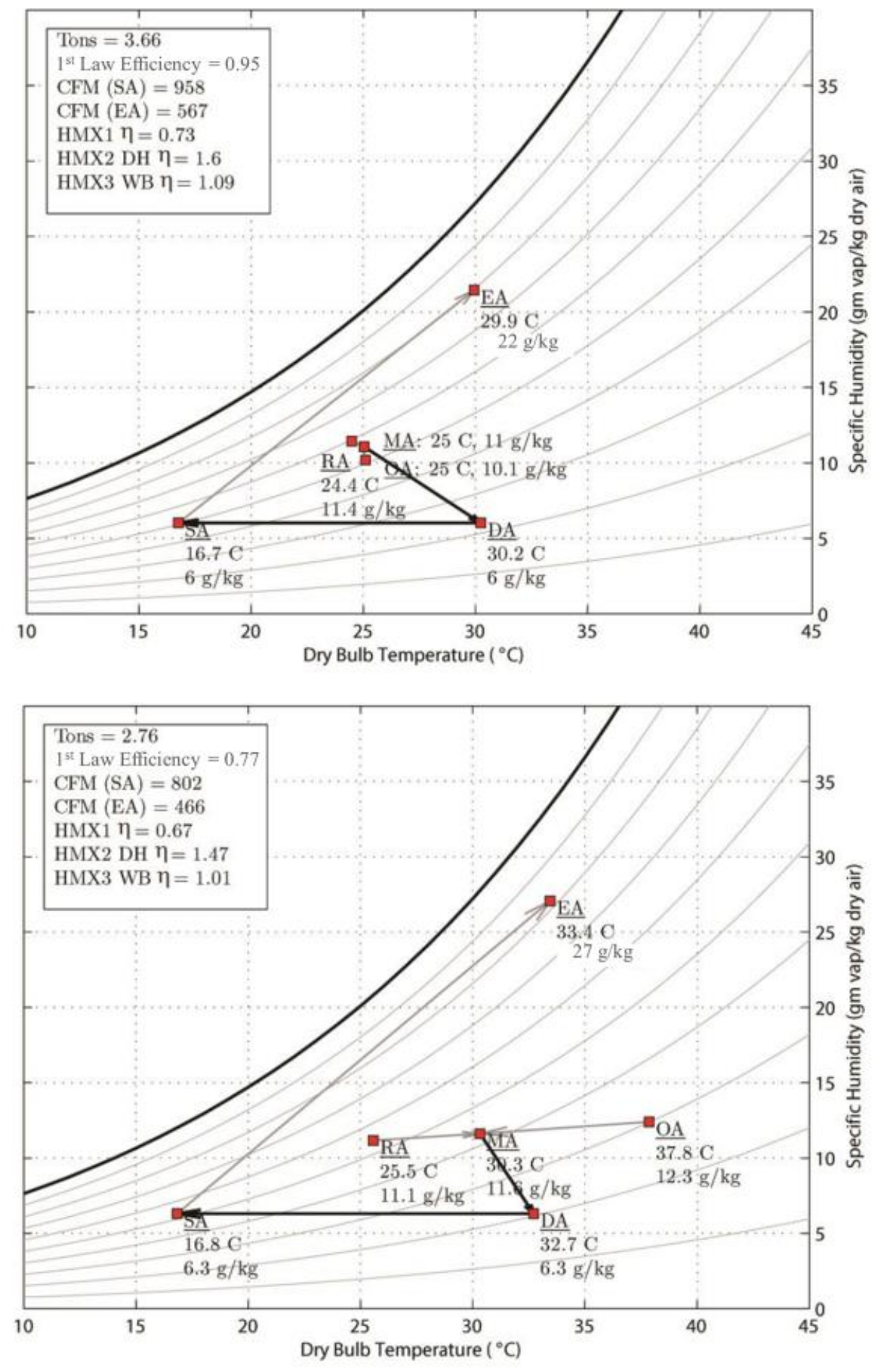

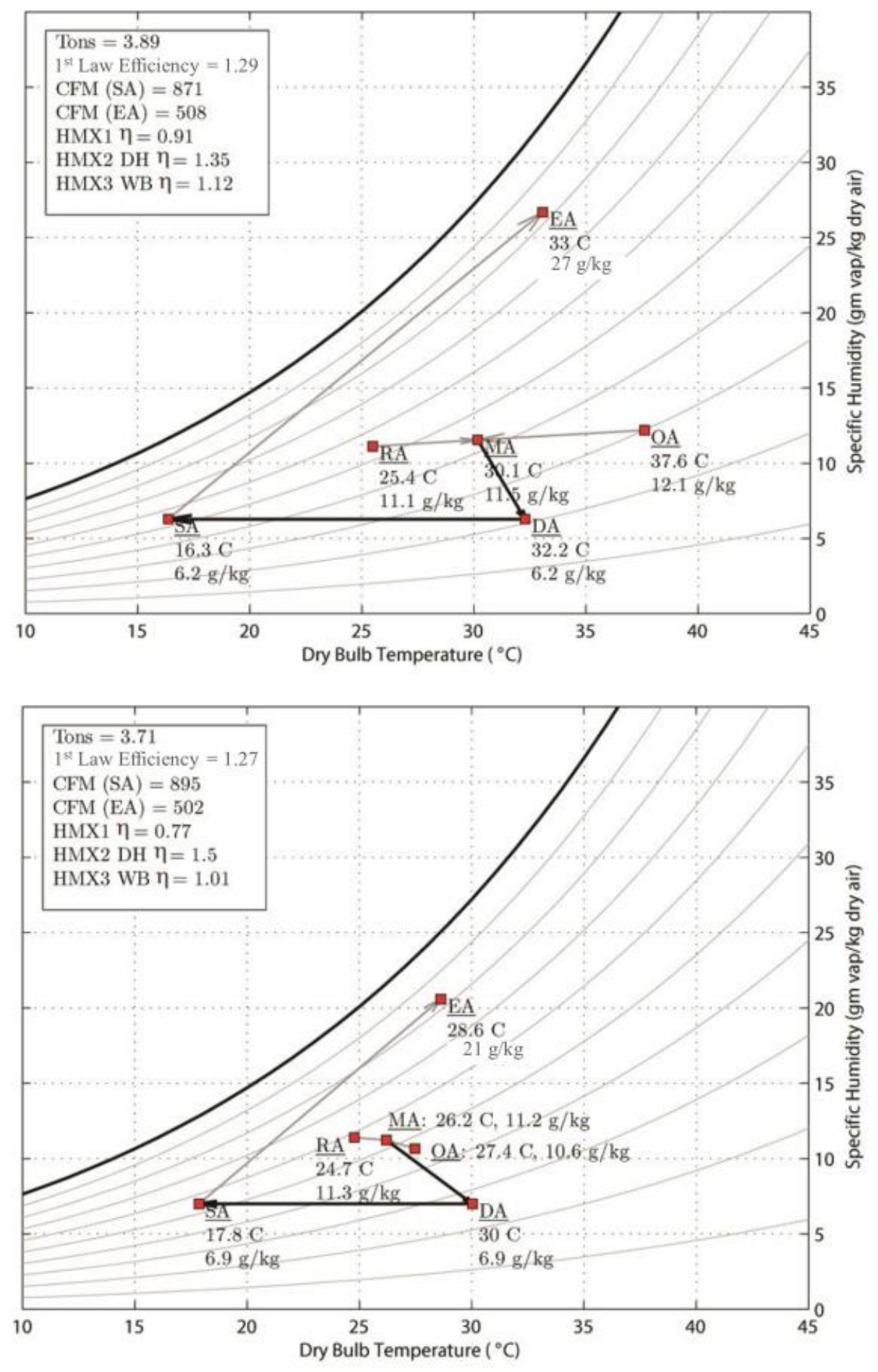

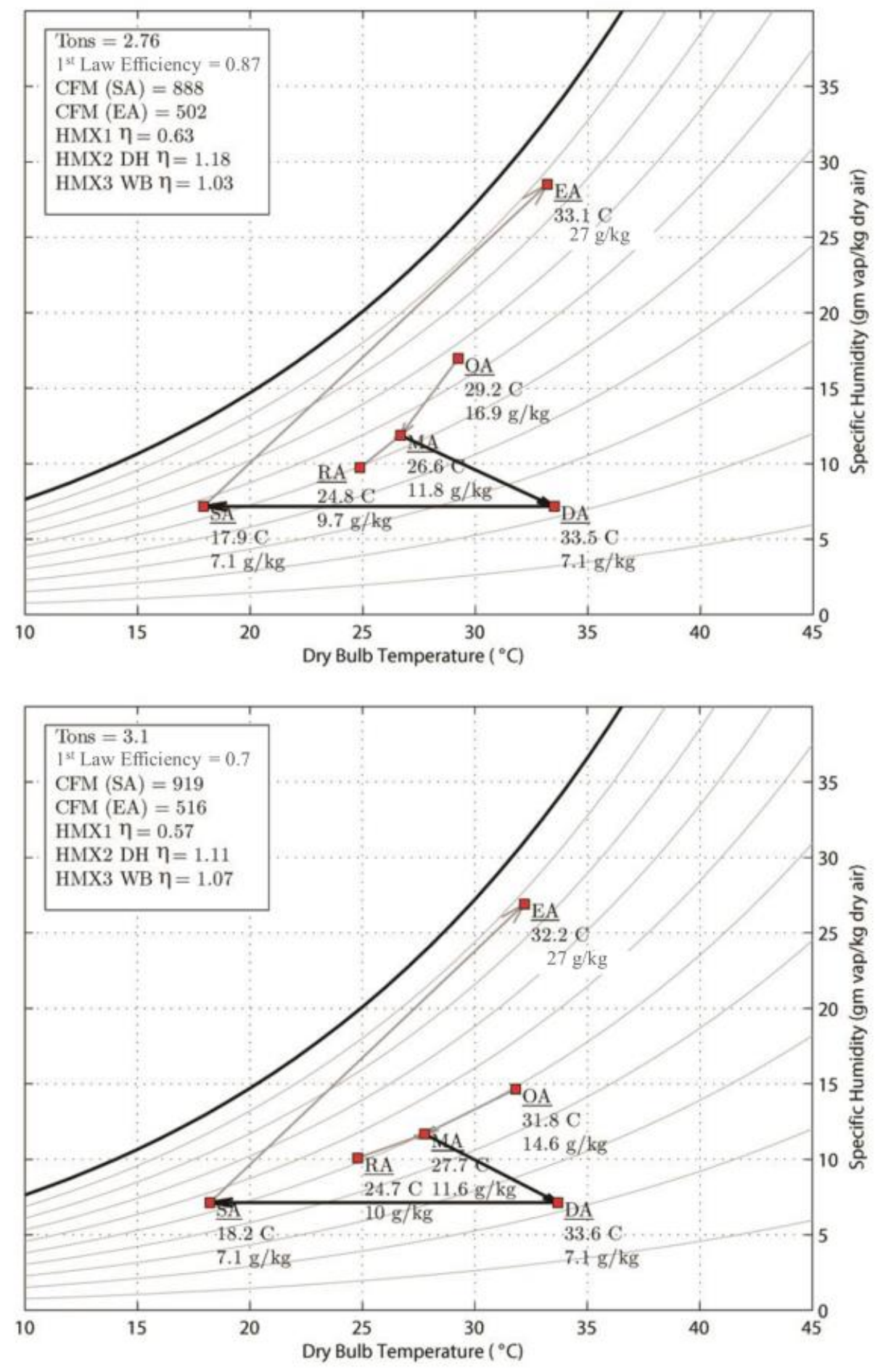

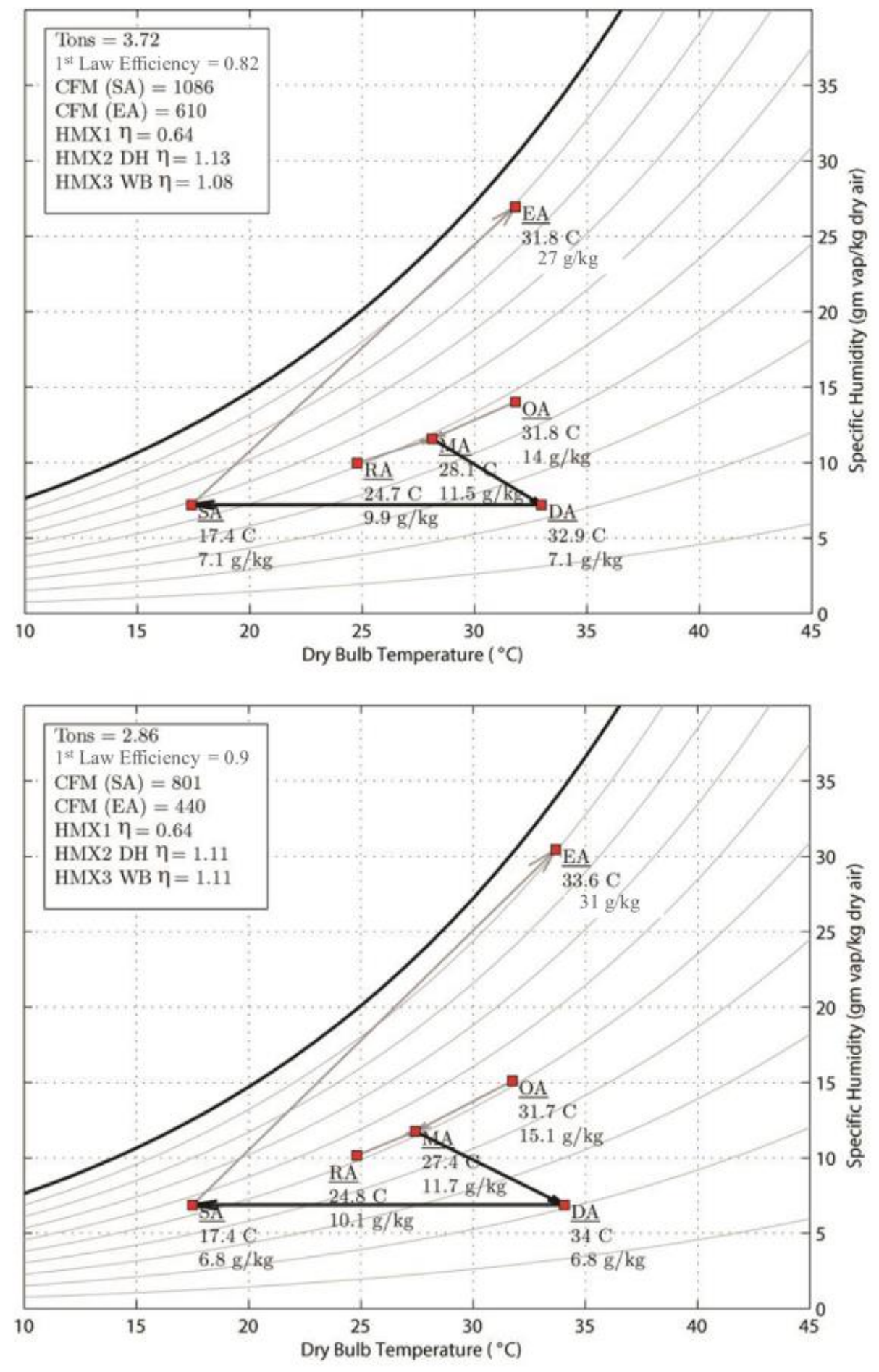

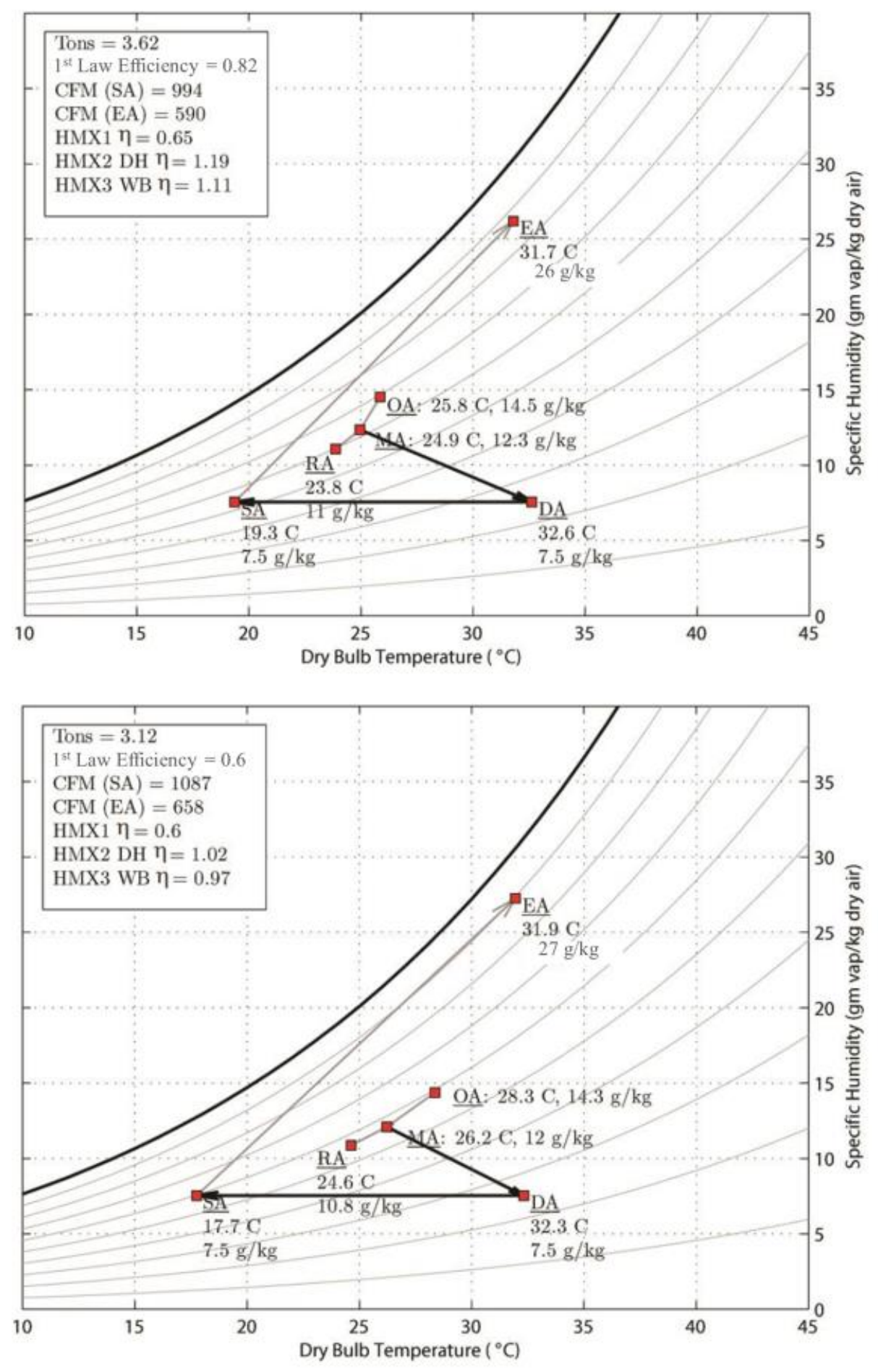

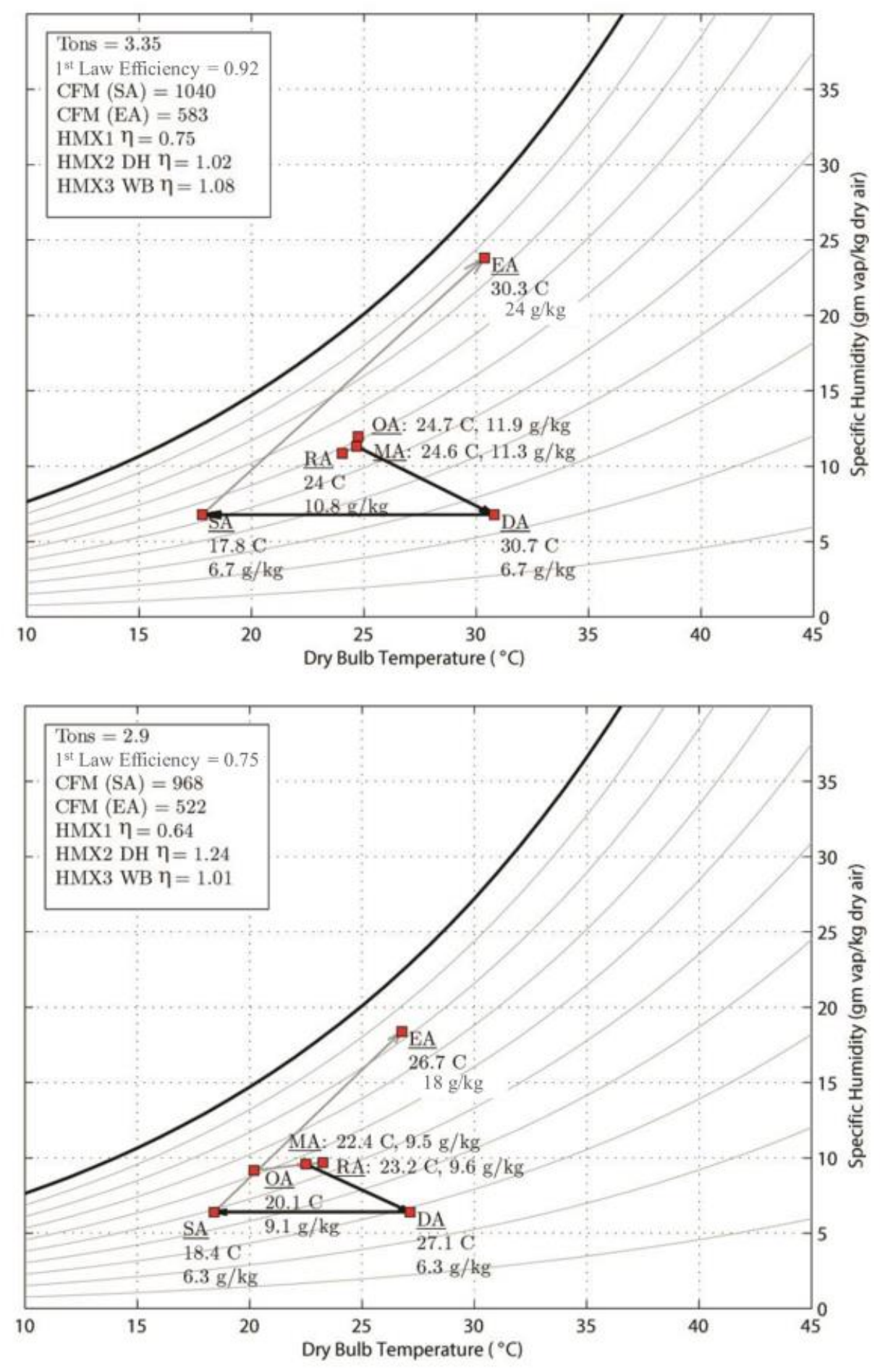

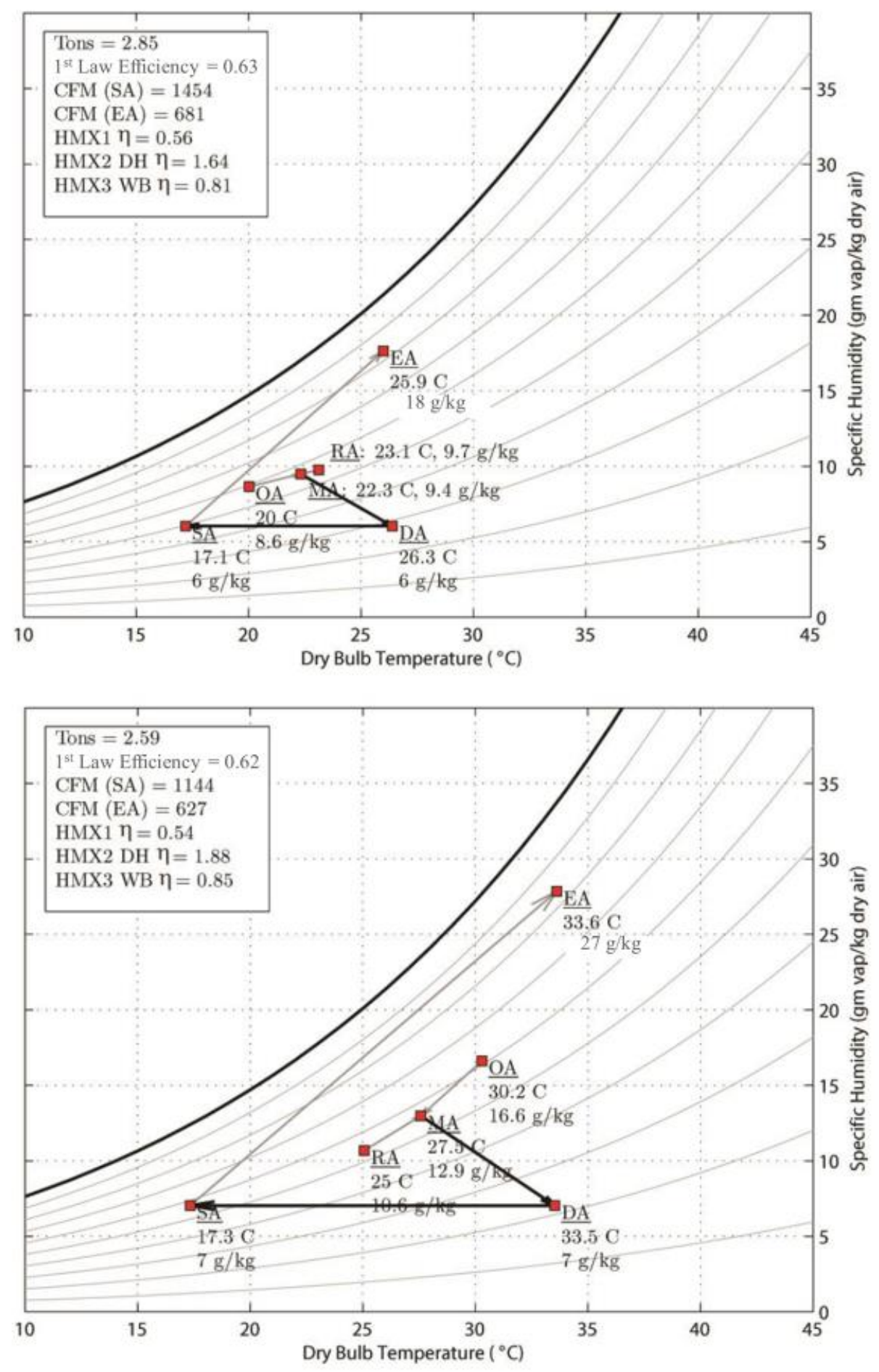

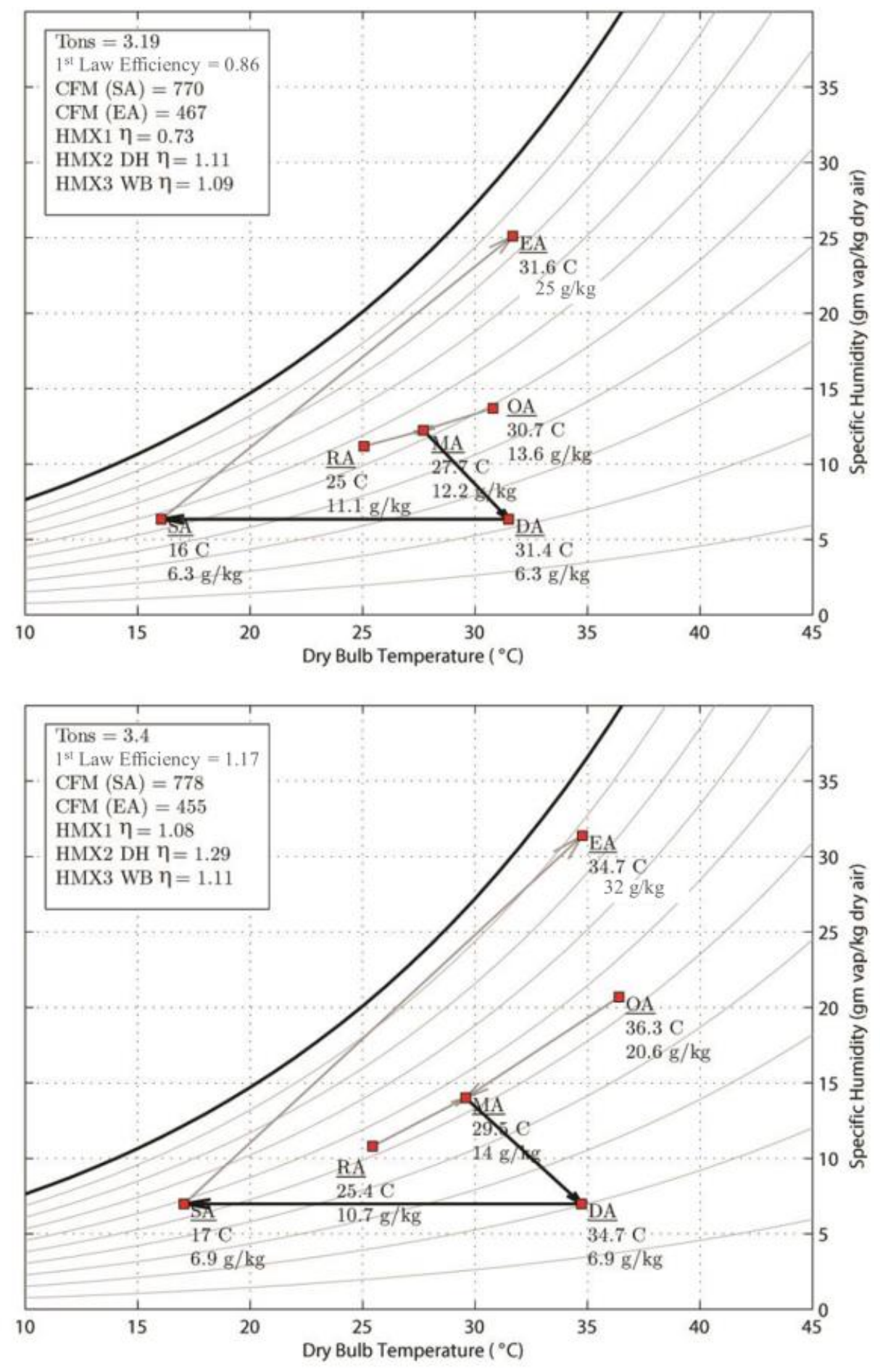

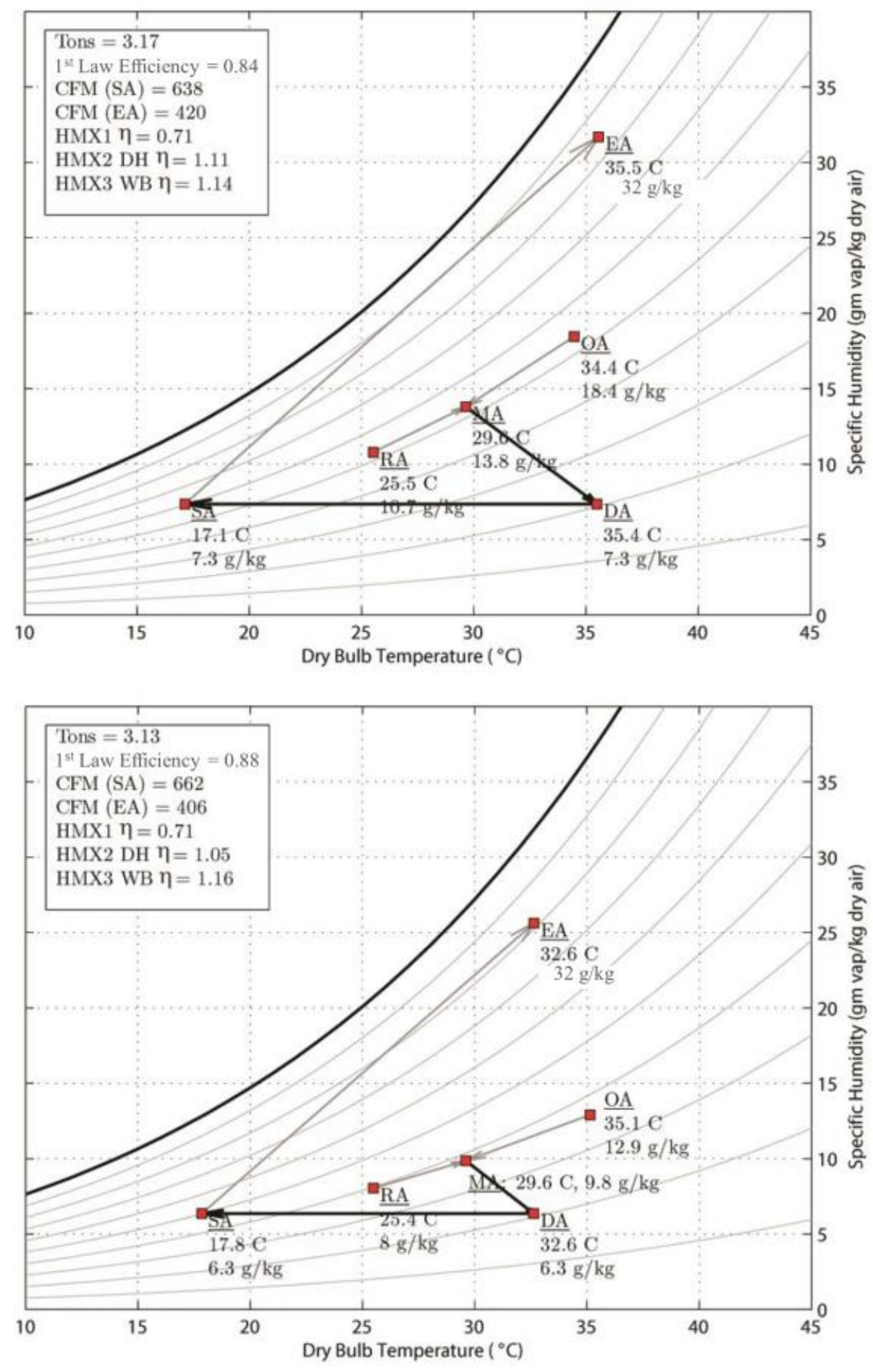

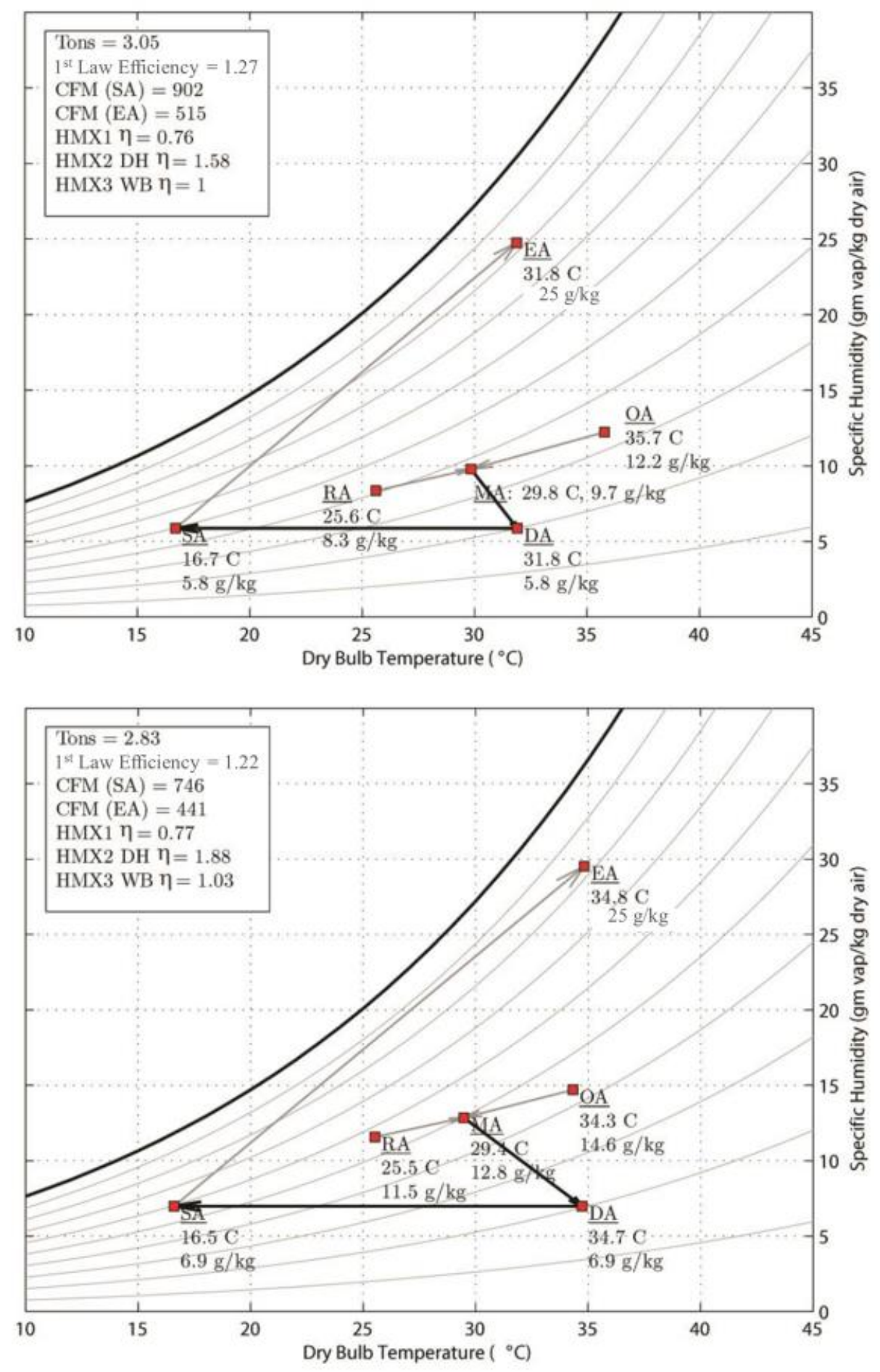
